\title{
Life cycle environmental evaluation of kettles: Recommendations for the development of eco-design regulations in the European Union
}

DOI:

10.1016/j.scitotenv.2017.12.262

\section{Document Version}

Accepted author manuscript

Link to publication record in Manchester Research Explorer

Citation for published version (APA):

Gallego Schmid, A., Jeswani, H., Fernandez Mendoza, J. M., \& Azapagic, A. (2018). Life cycle environmental evaluation of kettles: Recommendations for the development of eco-design regulations in the European Union. Science of the Total Environment, 625. https://doi.org/10.1016/j.scitotenv.2017.12.262

Published in:

Science of the Total Environment

\section{Citing this paper}

Please note that where the full-text provided on Manchester Research Explorer is the Author Accepted Manuscript or Proof version this may differ from the final Published version. If citing, it is advised that you check and use the publisher's definitive version.

\section{General rights}

Copyright and moral rights for the publications made accessible in the Research Explorer are retained by the authors and/or other copyright owners and it is a condition of accessing publications that users recognise and abide by the legal requirements associated with these rights.

\section{Takedown policy}

If you believe that this document breaches copyright please refer to the University of Manchester's Takedown Procedures [http://man.ac.uk/04Y6Bo] or contact uml.scholarlycommunications@manchester.ac.uk providing relevant details, so we can investigate your claim.

\section{OPEN ACCESS}




\title{
Life cycle environmental evaluation of kettles: Recommendations for the development of eco-design regulations in the European Union
}

Alejandro Gallego-Schmid*, Harish Kumar Jeswani, Joan Manuel F. Mendoza and Adisa Azapagic

Sustainable Industrial Systems, School of Chemical Engineering and Analytical Science, The University of Manchester, The Mill, Sackville Street, Manchester M13 9PL, UK

(*) Corresponding author: alejandro.gallegoschmid@manchester.ac.uk

\begin{abstract}
Between 117-200 million kettles are used in the European Union (EU) every year. However, the full environmental impacts of kettles remain largely unknown. This paper presents a comprehensive life cycle assessment of conventional plastic and metallic kettles in comparison with eco-kettles. The results show that the use stage contributes $80 \%$ to the impacts. For this reason, the eco-kettle has over $30 \%$ lower environmental impacts due to a greater water efficiency and related lower energy consumption. These results have been extrapolated to the EU level to consider the implications for proposed eco-design regulations. For these purposes, the effects on the impacts of durability of kettles and improvements in their energy and water efficiency have been assessed as they have been identified as two key parameters in the proposed regulations. The results suggest that increasing the current average durability from 4.4 to seven years would reduce the impacts by less than $5 \%$. Thus, improving durability is not a key issue for improving the environmental performance of kettles and does not justify the need for an eco-design regulation based exclusively on it. However, improvements in water and energy efficiency through eco-design can bring relevant environmental savings. Boiling the exact amount of water needed would reduce the impacts by around a third and using water temperature control by further $2 \%-5 \%$. The study has also considered the effects of reducing significantly the number of kettles in use after the UK (large user of kettles) leaves the EU and reducing the excess water typically boiled by the consumer. Even under these circumstances, the environmental savings justify the development of a specific EU eco-design regulation for kettles. However, consumer engagement will be key to the implementation and achievement of the expected environmental benefits.
\end{abstract}

Keywords: electrical and electronic equipment; life cycle assessment (LCA); energy and water efficiency; resource consumption; durability; European regulation.

\section{Introduction}

Electrical appliances and electronic products generate environmental impacts in all stages of their life cycle (Andrae, 2016), from extraction and production of raw materials, to manufacture and use, to end-of-life waste management. This has been demonstrated by many authors who have analysed different devices such as: televisions (Thomas et al., 2012), refrigerators (Monfared et al., 2014), laptops (Deng et al., 2011), mobile phones (Yu et al., 2010), digital cameras (Park et al., 2007), vacuum cleaners (Gallego-Schmid et al., 2016) and microwaves (Gallego-Schmid et al., 2018). Several life cycle assessment (LCA) studies have also been carried out for kettles, considering electricity and water consumption associated with their use when analysing environmental impacts of hot drinks. Examples include making tea (Azapagic et al., 2016; Cichorowski et al., 2015) or instant coffee (Humbert et al., 2009; Büsser and Jungbluth, 2009) which suggest that energy used by kettles is a key contributor to the impacts of the hot drinks. However, in these studies, other 
life cycle stages of kettles, such as their production, transport or end-of-life, were not considered. As far as we are aware, only four LCA studies are available in the literature that focused specifically on kettles, one of which was based in the UK (AEA Technology, 2008a,b), one in the Netherlands (VHK, 2010) and the remaining two were carried out at the European Union (EU) level (Fischer et al., 2014; van Elburg et al., 2011). However, they also considered only the use stage, focusing on global warming potential or primary energy consumption. The rest of the life cycle was either omitted completely or aggregated data were used from the Methodology for Eco-design of Energy-related Products (MEErP) EcoReport tool (Kemna et al., 2011). The authors (Fischer et al., 2014) acknowledged in their study that the MEErP EcoReport tool could have under-estimated the impacts from the production of kettles. Similar was also demonstrated in LCA studies of some other devices, including computers (Hopkinson and James, 2011). However, inventory data for other life cycle stages of kettles are limited, incomplete or of insufficient quality (WRAP, 2010; Telenko and Seepersad, 2010). The above discussion suggests that a comprehensive LCA study of kettles considering a range of impacts across the life cycle is not available in the literature.

The environmental importance of kettles in the $\mathrm{EU}^{1}$ is demonstrated by the fact that these devices have been included in the preparatory studies for establishing the Eco-design Working Plans for 2012-2014 (van Elburg et al., 2011) and 2015-2017 (Fischer et al., 2014). These studies provide background information and analysis to allow the European Commission to select an indicative list of energy-related product groups with high potential for environmental improvements. These devices will then be prioritised for the adoption of improvement measures through development of specific eco-design regulations over the next three years. In the preparatory study for 2012-2014 (van Elburg et al., 2011), kettles were ranked $13^{\text {th }}$ out of the 36 energy-related product groups, but only eight groups were selected for the development of specific eco-design regulations (European Commission, 2012). Nevertheless, the EU preparatory study concluded that significant water and energy savings (up to $37 \mathrm{PJ} / \mathrm{yr}$ in 2030) could be achieved for kettles through eco-design measures. The study also concluded that electric kettles have received relatively limited interest as the subject of environmental studies and identified use of material to manufacture kettles as a relevant criterion from the environmental perspective.

In a subsequent preparatory study for the Working Plan 2015-2017 (Fischer et al., 2014), kettles were proposed to the European Commission as a priority for future development of a specific eco-design regulation, considering that there are between 117-200 million units with an estimated electricity consumption of 19.5-33.3 TWh/yr. This report suggested that the increase in the durability and the reduction of electricity consumption through eco-design could potentially reduce 42.8-73.2 PJ of primary energy demand, $5040 \mathrm{t}$ of non-hazardous waste and $354 \mathrm{~kg} \mathrm{Ni}$ eq. of heavy metals emission to air. But, the preparatory study acknowledged that the data on the durability of kettles in the EU were unreliable and highly uncertain as extensive independent data were not available. Therefore, it remains unclear whether the savings in resource consumption would be sufficient to justify an eco-design obligation on durability. For energy and water savings, according to the above-mentioned EU preparatory study (Fischer et al., 2014), the two major eco-design challenges are to reduce the switch-off time of the kettle when the water starts to boil and the excess amount of water used. The former remains under debate as it has been criticised by manufacturers (CECED, 2014), arguing that it is necessary for the water to boil long enough for water to reach $100^{\circ} \mathrm{C}$ to kill the bacteria - while this is important in areas with less-stringent water treatment regulations, it is less relevant to the EU. On the other hand, all studies concur that overfilling the kettle is a critical issue from an environmental perspective (AEA Technology 2008 a,b; VHK, 2010; van Elburg et al., 2011; Murray et al., 2015; Sauer and Rüttinger, 2004). Therefore, the environmental effects in the EU of changing the current durability of kettles and using eco-kettles, which enable dosing the exact amount of water needed, are assessed

\footnotetext{
${ }^{1}$ If not stated otherwise in the text, the term 'EU' includes the UK.
} 
in the present study. This kind of eco-kettle, which is already available on the market, also allows water to be heated to different temperatures, in the range from $80^{\circ} \mathrm{C}$ to $100^{\circ} \mathrm{C}$. Lower temperatures are also recommended for some common hot drinks, such as green tea or instant coffee, to preserve the taste (UK Tea \& Infusion Association, 2016; Clear, 2016). The environmental benefits of regulating the water temperature, which were not included in the latest EU preparatory studies, have also been analysed here.

Therefore, to address the above-mentioned issues, the main objectives of the present study are:

- to provide a comprehensive life cycle inventory and compare the life cycle environmental impacts of plastic, metallic and eco-kettles and identify opportunities for improvements;

- to assess the environmental effects in the 28 EU countries (EU28) of the implementation of eco-design proposals for kettles, related to water and energy efficiency and their durability; and

- to assess the necessity of a future EU eco-design regulation for kettles.

To our knowledge, this is the first study of its kind internationally.

\section{Methods}

To achieve the study objectives, the life cycle environmental impacts have been estimated using LCA as tool. The study has been carried out in accordance with ISO 14040/44 guidelines (ISO, 2006a,b), following the attributional approach. The inventory data and the assumptions are presented first individually for each of the three kettle types - plastic, metallic and eco-kettle - and then at the EU level, considering all the kettles in use in the EU28.

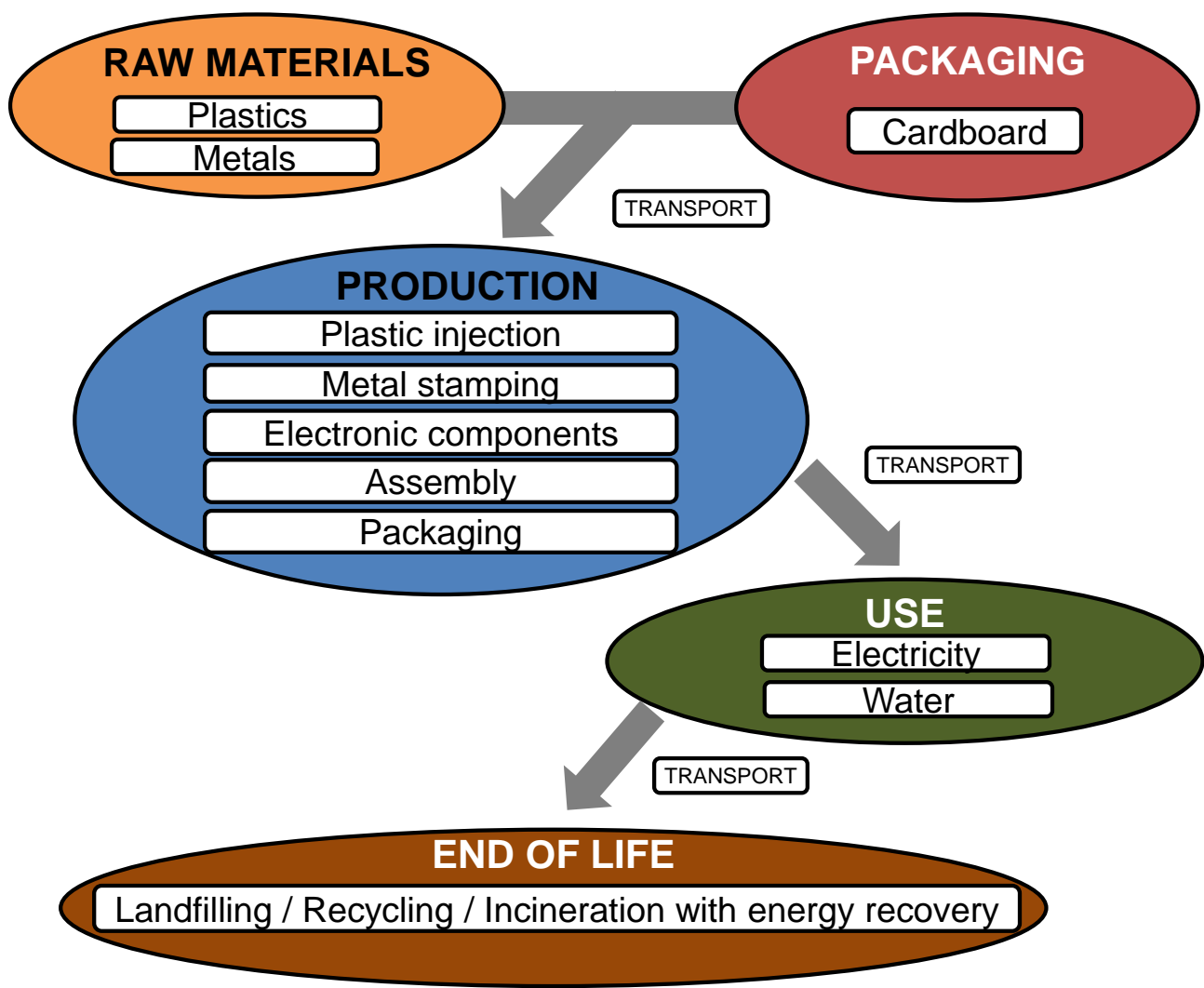

Fig. 1. System boundaries for the kettles considered in the study 


\subsection{Reference kettles}

\subsubsection{System description and boundaries}

Two main types of kettles are used in the EU: one with metallic (usually stainless steel) and another with plastic body (usually polypropylene), with a market split between the two of $40 \%$ and $60 \%$, respectively (VHK, 2010). The European kettle market is homogeneous and characterised by 1.5-2.0 L cordless kettles with power rating of 2200-3000 W, mainly produced in China (Fischer et al., 2014; Murray et al., 2015). Therefore, this study focuses on the comparison of two $3000 \mathrm{~W}$ cordless kettles made in China: polypropylene $(1.5 \mathrm{~L})$ and stainless steel $(1.7 \mathrm{~L})$, which are representative of the European market. Recently, some manufacturers have started to produce new models with eco-design improvements allowing for boiling of the required amount of water and at different temperature settings for different types of drink (Bosch, 2016; Hickman, 2010). Thus, such an eco-kettle is also considered here, with a polypropylene body and power rating of $2200 \mathrm{~W}$; as the other two kettles, it is also cordless and produced in China. This innovative design has a dual chamber body that allows users to boil the exact amount of water required, with the inner chamber having the capacity of $0.8 \mathrm{~L}$ and the outer $1.5 \mathrm{~L}$. It also allows a choice of three different water temperatures: $80^{\circ} \mathrm{C}$ (ideal for green tea), $90^{\circ} \mathrm{C}$ (ideal for instant coffee) or boiling (UK Tea \& Infusion Association, 2016; Clear, 2016).

The scope of the study is from 'cradle to grave'. The following stages have been considered for the three kettles (Fig. 1):

- raw materials:

- metals: stainless steel, aluminium, brass, copper, tin and silver (the latter only for the eco-kettle);

○ plastics: polypropylene (PP), polyvinyl chloride (PVC), nylon, polyoxymethylene (POM) polycarbonate $(P C)$, acrylonitrile butadiene styrene (ABS), high density polyethylene (HDPE) and silicone;

- cardboard and low density polyethylene (LDPE) (for packaging);

- production: plastic moulding and metal stamping, production of electronic components (internal cables, power cord, electric and thermal plugs, electronic control unit and thermal socket) and assembly and final packaging;

- use: consumption of electricity and water;

- end of life: disposal of post-consumer waste; and

- transport: packaging and raw materials to the production factory, kettles to retailer and, finally, end-of-life waste to management facility. The impacts associated to consumer transport to and from the retailer have not considered. The justification is the significant uncertainty related with consumer behaviour and with the allocation of impacts to kettles relative to other objects purchased at the same time. This is in line with the procedure established in the PAS 2050 standard (BSI, 2011) and followed other recent LCA studies (e.g. Amienyo et al., 2014).

The functional unit is defined as the 'use of the kettle to heat $1028 \mathrm{~L}$ of water annually'. This definition of the functional unit is based on the specifications provided by several studies in EU countries based on consumer enquires (Fischer et al., 2014; VHK, 2010; AEA Technology 2008a; Carbon Footprint, 2016). According to these studies, to heat this amount of water in a conventional kettle implies that $1542 \mathrm{~L}(1028 \mathrm{~L}$ plus $50 \%)$ of water is normally boiled, given that the kettles are usually overfilled on average by $50 \%$. For the eco-kettle it has been assumed that an exact amount of water needed is boiled, without any excess. The average lifetime of the kettle is assumed at 4.4 years (Fischer et al., 2014; VHK, 2010; AEA Technology 2008a). To estimate the environmental impacts at the EU level, the total number of kettles used in the EU28 over a year has been assumed at 145.2 million. This figure is based on the number of households in the EU28 countries in 2014 (Eurostat, 2016a) and assuming 0.67 kettles per household (van Elburg et al., 2011). 
Table 1. Inventory data for the plastic, metallic and eco-kettles

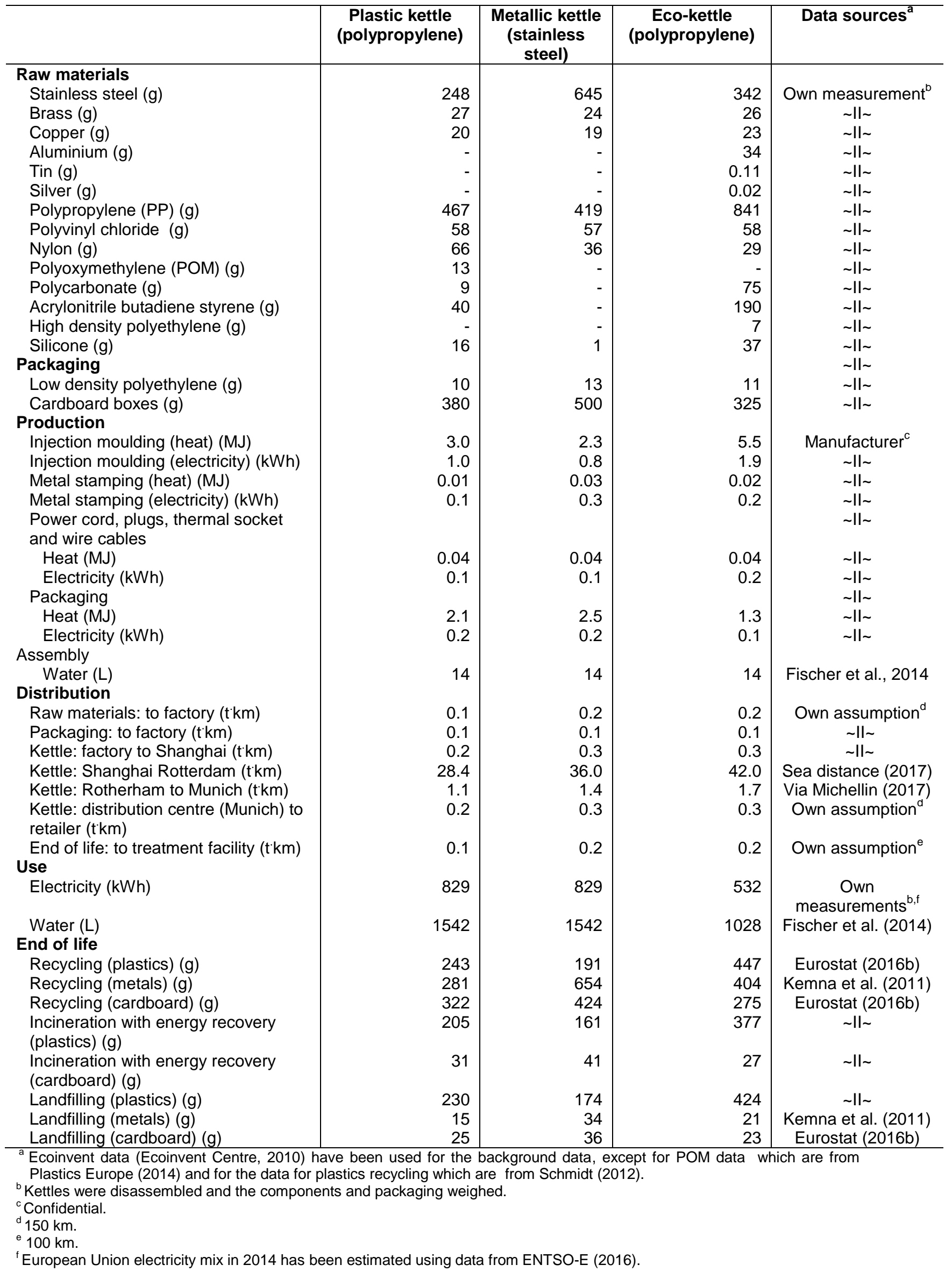




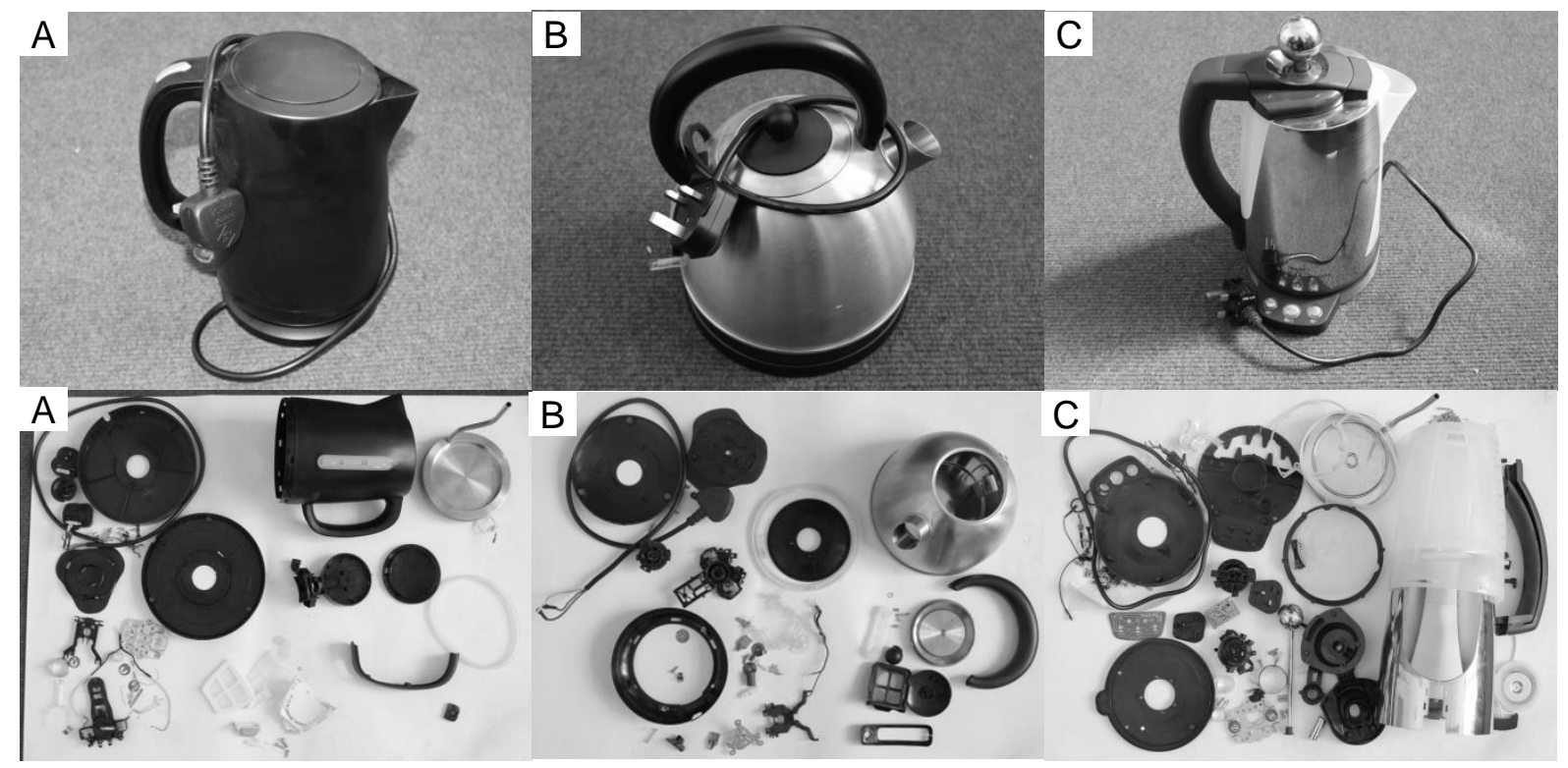

Fig. 2. Plastic $(A)$, metallic $(B)$ and eco $(C)$ kettles before and after dismantling

\subsubsection{Inventory data}

The life cycle inventory data for the three kettles are presented in Table 1; the kettle types and their constituent parts are shown in Fig. 2. Primary production data for the quantity and types of raw material and packaging as well as for the kettle production processes have been obtained from a major kettle producer in China. The Ecoinvent v2.2 database has been used for the background data (Ecoinvent centre, 2010); any data gaps have been filled using the $\mathrm{GaBi}$ database (Thinkstep, 2017) and the literature, as detailed in the next sections.

\subsubsection{Raw materials, production of kettles and packaging}

The three types of kettles have been dismantled into the constituent parts (Fig. 2) and weighed individually to obtain the bill of materials (Table 1). The total weight of the plastic kettle is $964 \mathrm{~g}$. The metallic components $(295 \mathrm{~g}$ ) are made of stainless steel (heating plate, screws and springs), brass (power cord plug and thermal plug and socket) and copper (plugs, power cord, wire cables and thermal socket). The plastic components $(669 \mathrm{~g})$ are made of PP (enclosure, main body, body bottom cover, lid, handle, base and filter and water gauge), PVC (plug, power cord and wire cables), nylon (thermal plug and socket), POM (lever system), PC (thermal socket), ABS (lid button and deck ring) and silicone (glass fibre tube and water window ring).

The metallic kettle has a total weight of $1201 \mathrm{~g}$. The metallic parts $(688 \mathrm{~g})$ are made of stainless steel (main body, heating plate, screws and springs), brass (power cord plug and thermal plug and socket) and copper (plugs, power cord, wire cables and thermal socket). The plastic components $(513 \mathrm{~g})$ are manufactured using PP (enclosure, bottom cover, lid, handle, base and filter and water gauge), PVC (wire cables, plug and power cord), nylon (thermal plug and socket) and silicone (glass fibre tube).

Finally, the eco-kettle weighs $1662 \mathrm{~g}$. The metallic part $(425 \mathrm{~g})$ are produced from stainless steel (heating plate and springs), brass (power cord plug and thermal plug and socket), copper (plugs, power cord, wire cables, thermal socket and electronic control unit), aluminium (screws), tin and silver (electronic control unit). The plastic components $(1237 \mathrm{~g})$ are made of PP (main body and enclosure, bottom cover, handle, base and filter and water gauge), PVC (power cord, plug and wire cables), nylon (thermal plug and socket and 
electronic control unit), PC) (lid and base), ABS (lid cover and external carcase), HDPE (electronic compound unit) and silicone (sealing rubbers).

Background data for all the materials have been obtained from the Ecoinvent database. The only exception is POM for which data are not available in Ecoinvent and have been sourced from Plastics Europe (2014) instead. The production of the kettles is located in China and, therefore, Ecoinvent data for the Chinese electricity grid have been used for all production processes. The injection moulding process is assumed for the shaping of the different plastic parts. Aluminium cold impact extrusion and steel stamping have been considered for the steel and aluminium components, respectively. For copper shaping, due to the absence of more specific data, Ecoinvent data for generic metal shaping have been used.

The packaging for the three types of kettle is similar and has been modelled using Ecoinvent data. The primary packaging is a folding box with interior protective carton boards (only for the metallic kettle) and a polyethylene bag to protect the appliance. Inventory data for folding board and the production of a cardboard box with offset printing have been used in the model. The interior boards have been modelled considering data for single-walled cardboard with mixed fibre. Low density polyethylene (LDPE) film has been assumed for the plastic bags. Finally, all three kettles use similar shipping boxes as secondary packaging. These boxes have been modelled using a double-wall cardboard made from recycled fibre.

The following assumptions have been made to fill data gaps and to adapt some datasets:

- For power cord, electrical and thermal plug and socket, Ecoinvent data for the production of computer cables and plugs have been adapted. The power cord is the same for the three kettles and H05VVH2-F $2 \times 0.75 \mathrm{~mm}^{2}$ has been considered. Based on own measurements, a copper weight of $14 \mathrm{~g} / \mathrm{m}$ has been assumed instead of the $19.5 \mathrm{~g} / \mathrm{m}$ in a standard computer cable. For the plugs and sockets, the Ecoinvent life cycle dataset has been adapted to reflect the specific mass of PP, brass, copper, nylon, PVC and PC used in each kettle.

- Due to a lack of data, electricity consumption for the assembly of the kettles has not been considered. However, water consumption (14 L) during the assembly and packaging production is included (Fischer et al., 2014).

\subsubsection{Use of kettles}

The consumption of electricity for each kettle to boil 1 to 4 cups of water ( $0.25 \mathrm{~L}$ per cup) has been obtained through own measurements; for details, see Table $\mathrm{S} 1$ in the Supporting information (SI). As the results are similar for each kettle, the average energy efficiency of $85 \%(0.122 \mathrm{kWh} / \mathrm{L}$ boiled water) is considered for all three types of kettle. This value is in line with the 90\% efficiency considered in other studies (VHK, 2010; Murray et al., 2015; AEA Technology 2008a). Based on these results and the average use of kettles to boil 1542 $L$ of water per year over a period of 4.4 years (Fischer et al., 2014; AEA Technology 2008a; VHK, 2010), the lifetime electricity consumption of the plastic and metallic kettles is $829 \mathrm{kWh}$ $(188.5 \mathrm{kWh} / \mathrm{yr})$. This is in range with studies from other EU countries: $167-217 \mathrm{kWh} / \mathrm{yr}$ (VHK, 2010; Fischer et al., 2014; AEA Technology 2008a,b; Zimmermann et al., 2012; EST, 2013).

The eco-design improvements (temperature selection and water efficiency) of the eco-kettle allow for reductions in electricity consumption to $532 \mathrm{kWh}(121 \mathrm{kWh} / \mathrm{yr})$ and water consumption to $1028 \mathrm{~L} / \mathrm{yr}$ (see section 2.1.3.1). The effect of this assumption has been tested through a sensitivity analysis to take into account consumer behaviour. In relation to durability, WRAP (2014) described the most frequent reasons for kettle failure and none was related to the material of the body and, therefore, the same lifetime (4.4 years) has been considered for all three kettle types. The impacts of the EU electricity mix in 2014 have been estimated using data from ENTSO-E (2016); see Table S2 in Supporting information. 


\subsubsection{End-of-life waste management}

The following assumptions have been made for the end-of-life stage:

- For metal waste, a 95\% recycling rate has been considered (Kemna et al., 2011; Xue et al., 2015) and the recycling process has been modelled using Ecoinvent data. The 'net scrap' approach (PE International, 2014) has been applied to credit the system for recycling. This approach considers the impacts associated with the recycling process and provides environmental credits of avoiding the use of virgin materials only for the amount of recycled metals that exceed the recycled content in the original raw materials. For example, steel is made up of $50 \%$ recycled and $50 \%$ virgin metal, therefore the system is credited for recycling $45 \%$ of steel (95\% minus 50\%). A similar approach has been considered for all other metals used as raw materials (copper, aluminium and brass).

- For end-of-life of plastic materials (PP, PVC, ABS, Nylon, PC, HPDE and POM), the following data for Europe in 2013 have been used: 38\% recycling, 31\% incineration with energy recovery and $31 \%$ landfilling (Eurostat, 2016b). The approach described above has been use to credit the system for recycled materials. The recycling process has been modelled with data from Schmidt (2012), but modified for the EU28 electricity mix in 2014 (ENTSO-E, 2016). The same electricity profile has been considered to credit the avoided impacts for the recovered electricity from incineration of plastic waste. All polyethylene bags and silicone are assumed to be landfilled.

- For the cardboard packaging, the packaging disposal data for the EU in year 2013 have been assumed: $85 \%$ recycling, $8 \%$ incineration with energy recovery and $7 \%$ landfilling (Eurostat, 2016b). The cardboard packaging is made from $85 \%$ of recycled material and, therefore, no credits have been considered for the avoided material.

\subsubsection{Transport}

Raw materials have been assumed to be transported to the factory in a 16-32 t Euro 3 truck over a distance of $150 \mathrm{~km}$. After the assembly and packaging in China, the kettles are shipped to Europe by a transoceanic freight ship to a distance of $19,500 \mathrm{~km}$, considering Shanghai and Rotterdam as the major container ports in China and Europe (World Ship Council, 2013). The kettles are then transported by a 16-32 t Euro 5 truck to a distribution centre in Munich $(830 \mathrm{~km})$, selected as geographically central point of the EU. The transport of the kettles from the production factory to the port in Shanghai (16-32 t Euro 3 truck) and from the distribution centre to the final retailer (16-32 t Euro 5 truck) has been modelled assuming common distances of $150 \mathrm{~km}$. Finally, end-of-life waste is transported for $100 \mathrm{~km}$ in a 16-32 t Euro 5 truck to the waste treatment facility.

\subsubsection{Environmental analysis at the EU level}

The environmental impacts of kettles at the EU level have been estimated by extrapolating the impacts for the plastic and metallic kettles and taking into account their respective market share (60\% and $40 \%)$. The total number of kettles in the EU28 ranges between 117200 million units. An intermediate value of 145.2 million kettles has been considered in the present study (see section 2.1.1). The analysis considers the effects on the impacts of two key factors explained in the next sections: improved energy efficiency and durability of kettles. These are further explored through a sensitivity analysis, as detailed in a subsequent section.

\subsubsection{Improving energy efficiency of kettles}

According to the Preparatory Working Plan (Fischer et al., 2014) the major focus of future regulations should be reducing electricity consumption when using the kettles. This is due to the facts that users have a tendency to boil more water than they need and have no 
possibility for selecting specific temperatures apart from the default $100^{\circ} \mathrm{C}$. This option is available for eco-kettles, which also allow the consumer to dose the exact amount of water they wish to use. Therefore, the environmental effects of implementation of these improvements at the EU level have been analysed through two scenarios and compared to the current situation. The current situation is the same as described in the previous sections and the two eco-design improvement scenarios - water dosing and temperature control are described below.

i) Improving water efficiency and related energy consumption: On average, EU users tend to overfill their kettles by at least 50\% (Murray et al., 2015; VHK 2010; van Elburg et al., 2011; Fischer et al., 2014; Sauer and Rüttinger, 2004). This means that the excess water is boiled unnecessarily, consuming excessive amounts of energy. Therefore, the amount of water boiled per year in the eco-kettle is $1028 \mathrm{~L}$ rather than $1542 \mathrm{~L}$ for the conventional kettles. This directly affects the consumption of electricity which reduces by a third, from the current $188.5 \mathrm{kWh} / \mathrm{yr}$ to $125.7 \mathrm{kWh} / \mathrm{yr}$. This is in line with the $31 \%$ reduction observed in an empirical study in the UK that compared the electricity consumed over a four week period by 77 people using a standard kettle and an eco-kettle which included a water control system (Product Creation, 2006). For the calculation of the impacts in this scenario, the inventory data are the same as defined for the eco-kettle in section 2.1.2 but without the electronic components and bottoms, which are used exclusively for temperature control (considered in the next section). To gauge the effect of a complete replacement of conventional kettles, the total number of eco-kettles considered in this scenario is equal to the number of kettles currently in use (145.2 million).

ii) Temperature control: Allowing the user to select the temperature to which they want to heat the water could not only save energy but improve the taste of their drink. For example, the temperature recommended for green tea is $70-80^{\circ} \mathrm{C}$, for instant coffee $90-95^{\circ} \mathrm{C}$ and $100^{\circ} \mathrm{C}$ for black tea (UK Tea \& Infusion Association, 2016; Clear, 2016). Only 65\% of boiled water (1002 L/kettle/yr) is used for hot drinks in the EU, as 35\% (540 L/kettle/yr) is for secondary applications, such as cooking potatoes, vegetables, pasta or rice (VHK 2010; Fischer et al., 2014). Based on national consumption data in the EU (Euromonitor International, $2014 \mathrm{a}, \mathrm{b})$, it has been calculated that $66 \%$ of the water is boiled for making tea (665 L/kettle/yr) and 34\% for instant coffee (337 L/kettle/yr). For the latter, this value is in line with the $300 \mathrm{~L} / \mathrm{kettle} / \mathrm{yr}$ proposed by Humbert et al. (2009). Of the tea consumed, $88 \%$ is black (585 L/kettle yr) and 12\% green tea (80 L/kettle/yr) (CBI Market Intelligence, 2015). Therefore, based on the type of drink, it has been calculated here that per volume of water heated, the kettle is used as follows: $5 \%$ of water at $80^{\circ} \mathrm{C}, 22 \%$ at $90^{\circ} \mathrm{C}$ and $73 \%$ at $100^{\circ} \mathrm{C}$. Considering the consumption of electricity by the eco-kettle at different temperatures (see Table S1 in the SI) and taking into account the percentage use at each, the electricity consumption per kettle with temperature control would be $181.4 \mathrm{kWh} / \mathrm{yr}$. As this scenario is independent of the water efficiency scenario, the original volume of $1542 \mathrm{~L}$ of water has been considered. Life cycle inventory data have been considered for this scenario as defined for the eco-kettle in section 2.1.2, but without considering the additional $400 \mathrm{~g}$ of PP necessary for a second chamber, as this change is related to the control of excess water. As before, the total number of kettles is 145.2 million.

\subsubsection{Improving durability of kettles}

The Preparatory Working Plan to establish the next EU eco-design regulations (Fischer et al., 2014) also suggested that the increase in durability should be one of the main foci of a future eco-design regulation for kettles. Several studies have considered the average durability of kettles between three and five years (AEA Technology 2008b; Cox et al., 2013; Defra, 2009; Ashby, 2013; Telenko and Seepersad, 2010; WRAP, 2012a,b; Kärnä and Malmström, 2002). In this study, an estimated lifetime of 4.4 years has been considered as assumed in some other studies (Fischer et al., 2014; AEA Technology 2008a; VHK, 2010). 
Manufacturers of better quality kettles claim that they test their kettles to last the equivalent to seven years of use (Fischer et al., 2014; WRAP, 2014). Therefore, the environmental impacts at the EU level have been calculated considering three durability lengths: three years (low durability), 4.4 years (current situation) and seven years (high durability). The number of kettles in use (145.2 million) in the EU28 has been estimated based on the number of houses in the EU28 countries in 2014 (Eurostat, 2016a) and assuming 0.67 kettles per household (van Elburg et al., 2011). The reference plastic and metallic kettles described in section above are a good representation of the homogenous EU market and, therefore, have been considered for the extrapolation of the impacts at the EU level. As mentioned earlier, the market share of $60 \%$ for plastic and $40 \%$ for metallic kettles has been assumed (VHK, 2010).

\subsubsection{Sensitivity analysis}

The sensitivity analysis considers the following key parameters that could affect the outcomes of the study: the number of kettles in use and the amount of water used in kettles. They are both related to the UK leaving the EU which could have a potentially high effect on the total impacts from kettles given that the UK is a significant user of this appliance. The amount of water used in kettles is also related to consumer behaviour, as explained further below.

i) Number of kettles in use: The current stock of kettles available in the EU is difficult to establish because the official data appear to be lower than industry estimates according to Fischer et al. (2014). The authors estimated a range of 117-200 million units, so that the 145.2 million considered in the present study is in that range. However, this range does not take into account the decision of the UK to leave the EU, known commonly as "Brexit". This could have significant implications for the EU impacts from kettles, given that $95 \%$ of 28.1 million households in the UK have a kettle (AEA Technology 2008 a,b; Defra 2009; Eurostat, 2016a; Palmer and Terry, 2014). Therefore, the lower estimate of the number of kettles in use in the EU without the UK would be 90.3 million (117 million minus 26.7 million). This value has been considered in the sensitivity analysis to evaluate the implications of the Brexit on the environmental impacts from kettles at the EU level.

ii) Amount of water used: The excess amount of water boiled in kettles is one of the parameters with higher uncertainty as it is greatly dependent on user behaviour, in addition to other aspects, like the size of the kettle or quantity of boiled water desired. Most of the studies (Fischer et al., 2014; VHK, 2010; AEA Technology 2008a; Carbon Footprint, 2016) considered a $50 \%$ water excess (a total of $1542 \mathrm{~L} / \mathrm{kettle} / \mathrm{yr}$ ). Another study in the Netherlands (Foekema et al., 2008), based on interviews of 2454 households, showed that excess water can be around 40\%. Furthermore, CECED (2014) suggested that the amount of water boiled for making tea in the EU could be overestimated, considering that tea consumption per capita in the whole of the EU is $15 \%$ of that in the UK (including the UK) and $3 \%$ if the UK is excluded. Therefore, the latter figure has been considered in combination with reducing the excess of water to $40 \%$. Thus, the total amount of water per kettle is assumed at $837 \mathrm{~L} / \mathrm{yr}$ ( $598 \mathrm{~L} / \mathrm{yr}$ plus $239 \mathrm{~L}$ for the $40 \%$ of excess water).

Thus, in summary, the sensitivity analysis considers the combined effect of reducing the total number of kettles in the EU to 90.3 million and the water volume to $837 \mathrm{~L} / \mathrm{kettle} / \mathrm{yr}$. These values have been used in the sensitivity analysis instead of the number of kettles and water volume assumed for the current situation and in the two improvement scenarios discussed in the section 2.1.3.1. The overall purpose is to find out if, even for the lowest water consumption and without the UK in the EU, the environmental benefits would still be sufficient to justify a specific EU eco-design regulation. 


\subsection{Environmental impact assessment}

GaBi v6.5 software (Thinkstep, 2017) has been used to model the system. The latest version of the CML 2001 (April 2015) impact assessment method (Guinee et al., 2001) has been applied to estimate the environmental impacts of the kettles. All 11 potential impacts included in the CML method are considered here, namely: depletion of elements, depletion of fossil resources, acidification, eutrophication, global warming, human toxicity, marine aquatic ecotoxicity, freshwater aquatic ecotoxicity, ozone depletion, photochemical oxidants and terrestrial ecotoxicity. In addition, primary energy demand (PED) has also been estimated using $\mathrm{GaBi}$.

\section{Results and discussion}

The results for the reference plastic, metallic and eco-kettles are discussed first in the next section. This is followed by the impacts at the EU level of full implementation of the durability and eco-design improvements in sections 3.2.1 and 3.2.2. These results are compared with those presented for kettles in the 2015-2017 preparatory study (Fischer et al., 2014) because this report forms the basis for prioritising energy-related products for development of eco-design regulations by the European Commission.

\subsection{Environmental impacts of kettles}

Fig. 3 compares the environmental impacts of the plastic, metallic and eco-kettles, disaggregated by life cycle stage. The results indicate that the use stage is the main hotspot for all the impact categories, contributing over $90 \%$ for the plastic and around $80 \%$ for the metallic the eco-kettles; this is due to the energy consumption to heat the water. The materials used to manufacture the kettles contribute only to three impacts: depletion of elements, human toxicity and terrestrial ecotoxicity ( $8 \%$ for the plastic kettles and $12 \%-16 \%$ for the other two types). The impacts from the kettle manufacture and transportation are small $(<4 \%$ and $1 \%$, respectively). Recycling of materials reduces depletion of elements by $6 \%$ because of the recycling credits; some other impacts are also reduced but only marginally $(<1.5 \%)$. For further details on the contribution of different life cycle stages to the impacts, see Tables S3-S5 in the SI.

As also shown in Fig. 3, the metallic and plastic kettles will use a similar amount of primary energy ( 10.5 GJ) and emit a similar amount greenhouse gases (400 and $399 \mathrm{~kg} \mathrm{CO} 2$ eq., respectively) over their service lives. These values are much lower for the eco-kettle, which will use $6.8 \mathrm{GJ}$ of primary energy and generate $262 \mathrm{~kg} \mathrm{CO}_{2}$ eq.

All the other impacts are higher for the metallic kettle than for the plastic, but for most the difference is small $(<2 \%)$. The only exceptions are depletion of elements, human toxicity and terrestrial ecotoxicity, where the difference is 5\%-10\% in favour of the plastic kettle. The ecokettle has 30\%-35\% lowest impacts than the plastic and $32 \%-38 \%$ than the metallic as it consumes less energy over the lifetime.

However, the eco-kettle has slightly higher impacts for eight categories if the use stage is not considered. This is due to the need for more electronic components and an additional (polypropylene) chamber to control the temperature and the amount of water to be boiled, respectively. Nevertheless, these impacts are clearly outweighed by the savings achieved in the use stage. Thus, improvements in the energy efficiency of the kettles are key to improving their environmental performance. The effect of this at the EU level is discussed in the next section. 


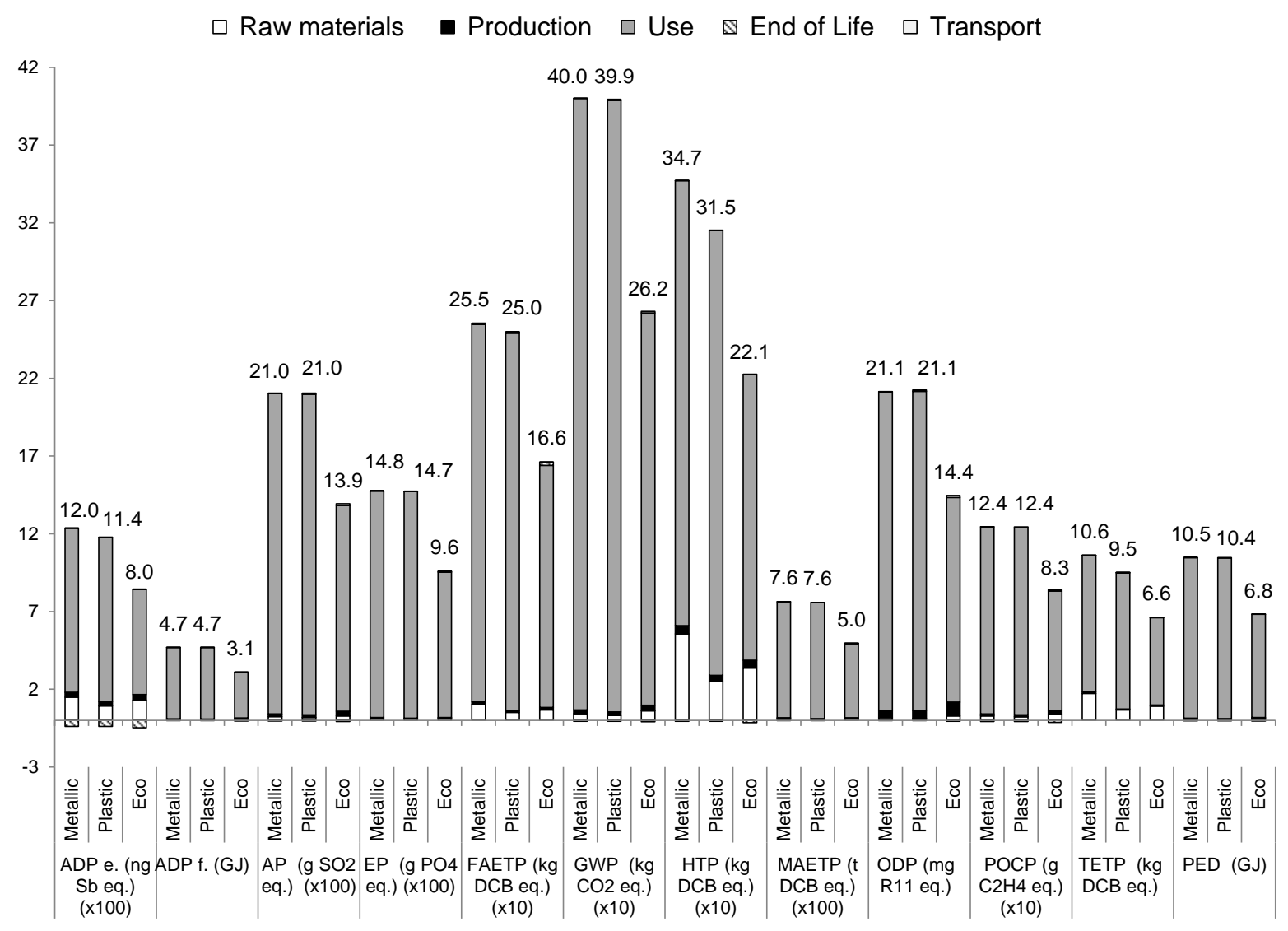

Fig. 3. Life cycle environmental impacts of plastic, metallic and eco-kettles over their average useful lifetime (4.4 years).

[The values shown in the figure represent the total impact after the system credits have been applied and for some impacts should be multiplied by the factor shown in brackets to obtain the original values. ADP e.: abiotic depletion potential of elements, ADP f.: abiotic depletion potential of fossil resources, AP: acidification potential, EP: eutrophication potential, GWP: global warming potential, HTP: human toxicity potential, MAETP: marine aquatic ecotoxicity potential, FAETP: freshwater aquatic ecotoxicity potential, ODP: ozone layer depletion potential, POCP: photochemical ozone creation potential, TETP: terrestrial ecotoxicity potential, PED: primary energy demand and DCB: dichlorobenzene.]

\subsection{Environmental analysis at the EU level}

\subsubsection{Improving the energy efficiency of kettles: water use and temperature control}

The annual environmental impacts from the kettles at the EU level are shown in Fig. 4 for the current situation and for the two scenarios for reducing the electricity consumption: i) improved water efficiency through dosing the exact amount of water needed; and ii) temperature control (see section 2.1.3.1 for details). The results suggest that the improved water efficiency would reduce the impacts by $31 \%-33 \%$ while the temperature control would lower them by only $2-5 \%$. The reason for the latter is the dominant influence of electricity consumed in the use stage (see Table S6 in the SI).

In their preparatory study for EU eco-design regulations, Fischer et al. (2014) considered that devices with a primary energy demand saving potential above the $7 \mathrm{PJ} / \mathrm{yr}$ threshold should be considered as a potential case for a specific EU eco-design regulation. As indicated in Fig. 4 and, the results obtained in this work show that the primary energy demand can be reduced from the current $345 \mathrm{PJ} / \mathrm{yr}$ to $232.6 \mathrm{PJ} / \mathrm{yr}$ (a reduction of 112.4 $\mathrm{PJ} / \mathrm{yr}$ in Table 2) or to $332.7 \mathrm{PJ} / \mathrm{yr}$ (a saving of $12.3 \mathrm{PJ} / \mathrm{yr}$ ) in the two respective scenarios. 
Thus, both improvement values are much above the $7 \mathrm{PJ} / \mathrm{yr}$ threshold, rendering kettles a strong candidate for the development of an eco-design regulation. Fischer et al. (2014) also estimated that the current primary energy demand can potentially be reduced by $42.8-73.2$ $\mathrm{PJ} / \mathrm{yr}$ through the implementation of best available technologies for kettles. These are mainly aimed at reducing the switch-off time of the kettle when the water starts to boil and the excess amount of water used. Table 2 shows that their estimated values are too conservative because just the implementation of the water-efficiency scenario alone would reduce the energy consumption by 1.5-2.6 times (112.4 PJ/yr versus 42.8-73.2 PJ/yr) on the improvement potential estimated by Fischer et al. (2014).

Fischer et al. (2014) considered abiotic resource saving potential as a second criterion for selection, but unlike energy demand, the assessment was carried out only at a qualitative level (see Table 2). The study concluded that for kettles "the size of resource consumption saving is uncertain and may not be significant". However, the two scenarios considered in this study demonstrate that the reduction in the consumption of abiotic resources would be significant (31\% for the water-efficiency $2 \%$ for the temperature-control scenarios). They are related mainly to the reduced consumption of copper and lead used in electricity transmission. Furthermore, these energy saving measures would also reduce consumption of fossil fuels. For example, compared to the current situation, the implementation of the water-efficiency scenario would save $4276 \mathrm{t} \mathrm{Cu} / \mathrm{yr}$ and $2539 \mathrm{kt}$ coal/yr, while the temperature-control scenario would avoid the use of $476 \mathrm{t} \mathrm{Cu} / \mathrm{yr}$ and $280 \mathrm{kt}$ coal/yr.

Fischer et al. (2014) also considered qualitatively other environmental aspects, such as the presence of toxic substances, direct emissions to air, water and soil as well as the consumption of water in the use stage, but only if the group of devices showed significant reduction potentials in primary energy demand or resources consumption. As shown in Table 2, the authors concluded that the implementation of eco-design improvements would not lead to other significant environmental benefits for kettles, except for water consumption in the use stage, for which the reduction potential was "high". Fischer et al. (2014) did not quantify the amount, but the current study shows that the implementation of the waterefficiency scenario would bring significant water savings at the EU level, equivalent to 74.5 $\mathrm{Mm}^{3} /$ year of water ( $512 \mathrm{~L} \times 145.2$ million kettles, assuming that the excess boiled water $(512$ $\mathrm{L} / \mathrm{kettle} / \mathrm{yr}$ ) is discarded rather than reused). This amount is similar to the water consumed for household purposes $\left(78.6 \mathrm{Mm}^{3}\right.$ ) by the whole population of Slovenia in 2012 (Eurostat, 2015).

With regard to toxic substances, human and eco-toxicities would be reduced by $31-32 \%$ for the water-efficiency scenario and by $4-5 \%$ for the temperature-control scenarios. These reductions are mainly due to the decrease in electricity consumption, specifically coal in the mix, and related emissions of heavy metals from coal mining. Other emissions related to coal mining and combustion $\left(\mathrm{SO}_{x}\right.$ and $\mathrm{NO}_{x}$ emissions to air and $\mathrm{PO}_{3}{ }^{4-}$ emissions to water) would also be lower, reducing acidification, eutrophication and photochemical oxidants by $31 \%-32 \%$ and $3 \%-4 \%$ in the respective scenarios. Furthermore, the lower consumption of natural gas for electricity would reduce emissions of halogenated organic compounds, leading to an overall reduction in the ozone layer depletion of $32 \%$.

Even though it is not specifically considered as a selection criterion in the preparatory studies for EU eco-design regulations, the reduction of greenhouse gas (GHG) emissions is a key environmental policy in the EU (European Parliament and European Council, 2009). The results of the scenario analysis in Fig. 4 show that the current global warming potential associated with the use of kettles in the EU can be reduced by $32 \%\left(4226 \mathrm{kt} \mathrm{CO}_{2}\right.$ eq./yr) in the water-efficiency scenario and by $3 \%(432 \mathrm{kt} \mathrm{CO}$ eq./yr) in the second scenario. To put these figures in context, the reduction associated with the water-efficiency scenario is more than double the GHG emissions (1921 kt CO 2 eq.) of Malta in 2012 (JRC, 2014). 


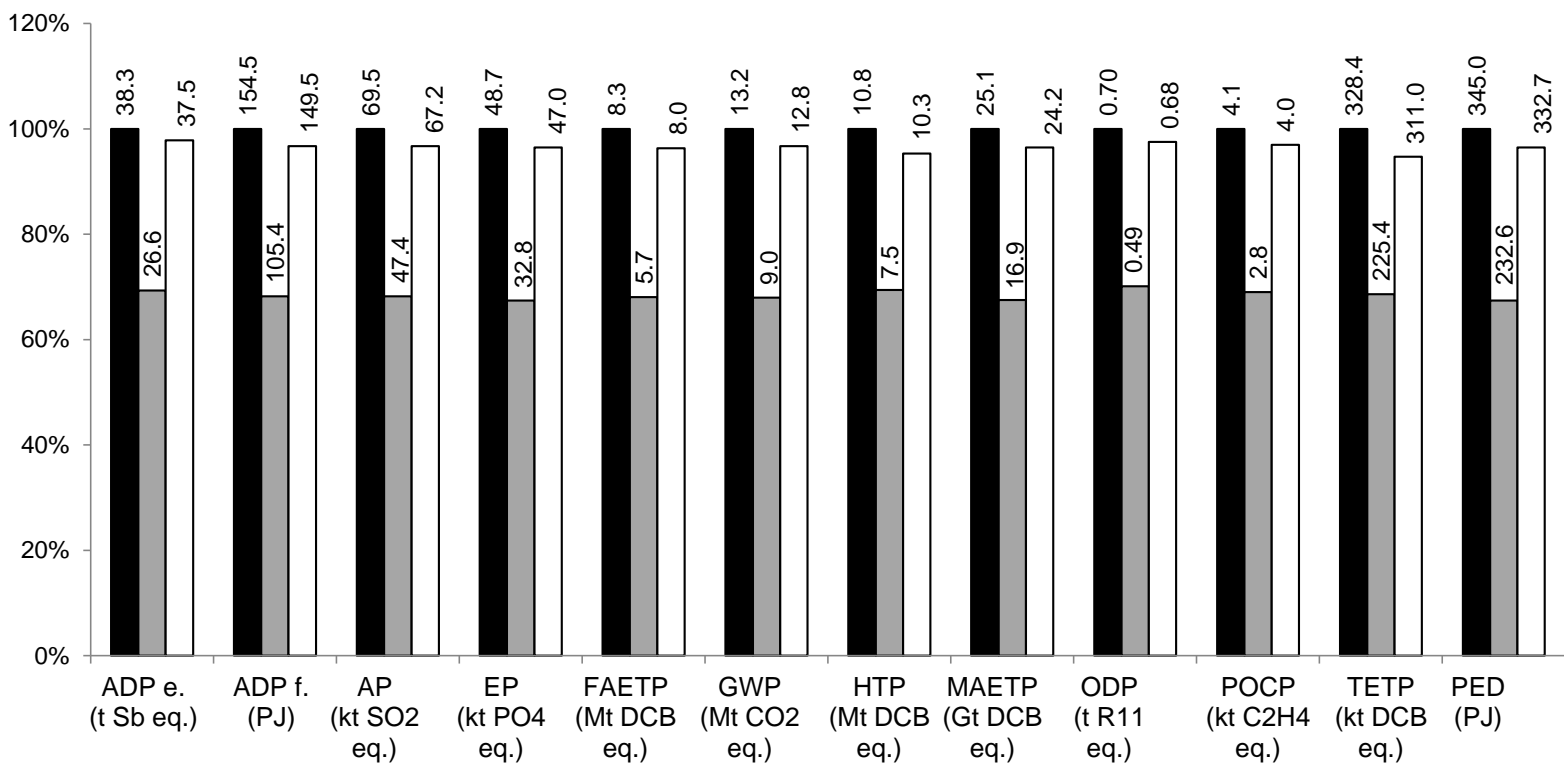

Fig. 4. Comparison of annual environmental impacts of kettles in the EU28 for the current situation and improved energy-efficiency scenarios: improved water efficiency and temperature control.

[Basis: 145.2 million kettles in use. The values shown on top of the bars are the total impacts. For the description of the improved energy-efficiency scenarios, see section 2.1.3.1. For impacts nomenclature, see Fig. 3).

Table 2. Reduction of annual environmental impacts from kettles in the EU28 for different improvement options considered in this work in comparison with the improvements identified by the EU preparatory study for ecodesign regulations (Fischer et al., 2014).

\begin{tabular}{|c|c|c|c|c|}
\hline Impacts $^{a}$ & $\begin{array}{l}\text { EU preparatory } \\
\text { study }^{b}\end{array}$ & $\begin{array}{c}\text { Temperature } \\
\text { control }\end{array}$ & $\begin{array}{c}\text { Improved water } \\
\text { efficiency }\end{array}$ & $\begin{array}{l}\text { Increase in } \\
\text { durability }^{c}\end{array}$ \\
\hline ADP e. (t Sb eq.) & Medium $^{\mathrm{d}}$ & 0.8 & 11.8 & 1.3 \\
\hline ADP f. (PJ) & - & 5.0 & 49.2 & 1.0 \\
\hline $\mathrm{AP}$ (kt SO 2 eq.) & Low & 2.3 & 22.1 & 0.5 \\
\hline $\mathrm{EP}$ (kt $\mathrm{PO}_{4}$ eq.) & Low & 1.7 & 15.9 & 0.2 \\
\hline FAETP (Mt DCB eq.) & Low & 0.3 & 2.7 & 0.1 \\
\hline GWP (Mt $\mathrm{CO}_{2}$ eq.) & Low & 0.4 & 4.2 & 0.1 \\
\hline HTP (Mt DCB eq.) & Low & 0.5 & 3.3 & 0.5 \\
\hline MAETP (Gt DCB eq.) & Low & 0.9 & 8.1 & 0.2 \\
\hline ODP (t R11 eq.) & Low & 0.02 & 0.21 & 0.01 \\
\hline POCP (kt $\mathrm{C}_{2} \mathrm{H}_{4}$ eq.) & Low & 0.12 & 1.27 & 0.05 \\
\hline TETP (kt DCB eq.) & Low & 17.4 & 103.0 & 14.6 \\
\hline PED (PJ) & $42.8-73.2^{\mathrm{e}}$ & 12.3 & 112.4 & 1.4 \\
\hline $\begin{array}{l}\text { Water consumption } \\
\text { (use stage) }\left(\mathrm{Mm}^{3}\right)\end{array}$ & High & - & 74.5 & - \\
\hline
\end{tabular}

${ }^{\mathrm{a}}$ For impacts nomenclature see Fig. 3.

b Source: Fischer et al. (2014). The improvement potentials are based on the reduction of electricity consumption through eco-design and an increase in durability. The following environmental aspects are considered: toxic substances, direct emissions to air, water and soil, consumption of abiotic resources and water in the use stage.

${ }^{c}$ From 4.4 to seven years.

${ }^{\mathrm{d}}$ The resource consumption saving is uncertain and may not be significant (Fischer et al., 2014).

e Range based on the number of kettles estimated (117-200 million). The improvement of $7 \mathrm{PJ} / \mathrm{yr}$ is considered as a threshold for a specific EU eco-design regulation.

It can be concluded from these results that the possibility of implementing feasible and available eco-design solutions for kettles to boil the exact amount of water as needed, justifies by itself the necessity of developing a European eco-design regulation for kettles. This improvement would imply, compared with the current situation, reductions of over $30 \%$ in primary energy use and depletion of elements, which are the two main criteria considered 
by the European Commission for development of an eco-design regulation. Moreover, this improvement would also result in reductions of over 30\% for ten other impact categories and could decrease the amount of water consumed by up to $50 \%$. As demonstrated with the ecokettle, already available on the market, the required changes to the design are minimal and should not cause significant difficulties in the production process or increase in the costs to manufacturers or consumers: all that is required is a second chamber made of plastics. On the other hand, the benefits are relatively small (2-5\%) related to the temperature control of the water, suggesting that this eco-design improvement should not be prioritised in an EU eco-design regulation for kettles. Moreover, the need for additional electronic parts of the kettle could increase complexity and costs to manufacturers and consumers.

\subsubsection{Improving durability of kettles}

The effects of durability of kettles on the environmental impacts at the EU level are summarised in Fig. 5. A decrease in service life from the current 4.4 to three years would increase depletion of elements, human toxicity and terrestrial ecotoxicity by $4-6 \%$ and the other impacts by less than $2 \%$. Increasing the lifetime to seven years would have a similarly small effect, decreasing the above three impacts by $3-5 \%$ and the others by less than $1.5 \%$; global warming and primary energy demand would be lower by only $0.5 \%$. These results suggest that durability is not a key factor in the environmental performance of kettles and does not justify development of a specific eco-design regulation for the kettles based on this criterion.

As discussed in the previous section, another key factor considered by the European Commission is the primary energy saving potential that can be achieved with eco-design improvements. For kettles, a high increase in durability (from 4.4 to seven years) would save just $1.4 \mathrm{PJ} / \mathrm{yr}$. This is well below the threshold value of $7 \mathrm{PJ} / \mathrm{yr}$ considered by the EU preparatory study (Fischer et al., 2014) and hence does not qualify for a specific eco-design regulation. A further criterion considered by the European Commission, although to a lesser extent, is consumption of resources and critical raw materials. Only the chromium used in stainless steel is on the EU list of critical raw materials (European Commission, 2014), but has already been discarded as an issue because of relatively small amounts used in kettles (Fischer et al, 2014). Moreover, recovery of resources should not be problematic as the European Directive on waste electrical and electronic equipment (European Parliament, 2012 ) requires that $75 \%$ of their weight must be recovered.

It can be argued that increasing the durability of kettles is in line with principles of the circular economy, one of the major sustainability strategies of the EU (European Commission, 2015) as it reduces the use of materials and energy. However, as mentioned by Ellen MacArthur Foundation, for energy-using products, the optimal serviceable life must take into account improvements in energy performance over time (EMF, 2015). This is of special relevance for high electricity-consuming devices such as kettles as a significant increase in the durability can be detrimental from the environmental point of view if improvements in energy efficiency are expected in the near future. Therefore, any kettle regulations encouraging longer durability should ensure that best available technologies for energy-efficiency of kettles are also applied simultaneously.

\subsection{Sensitivity analysis}

This section explores the combined effects of two factors on the EU-level impacts: lower number of kettles in use due to the Brexit (90.3 million) and reduced volume of water boiled (837 L/kettle/yr), due to the Brexit and reduced excess of water, and the related reduction in electricity consumption. These values have been used instead of the number of kettles (145.2 million) and water volume (1542 L) assumed for the current situation and in the two improvement scenarios (for further details, see section 2.1.4). 
- Current durability (4.4 years) $\quad \square$ Low durability (3 years) $\quad \square$ High durability (7 years)

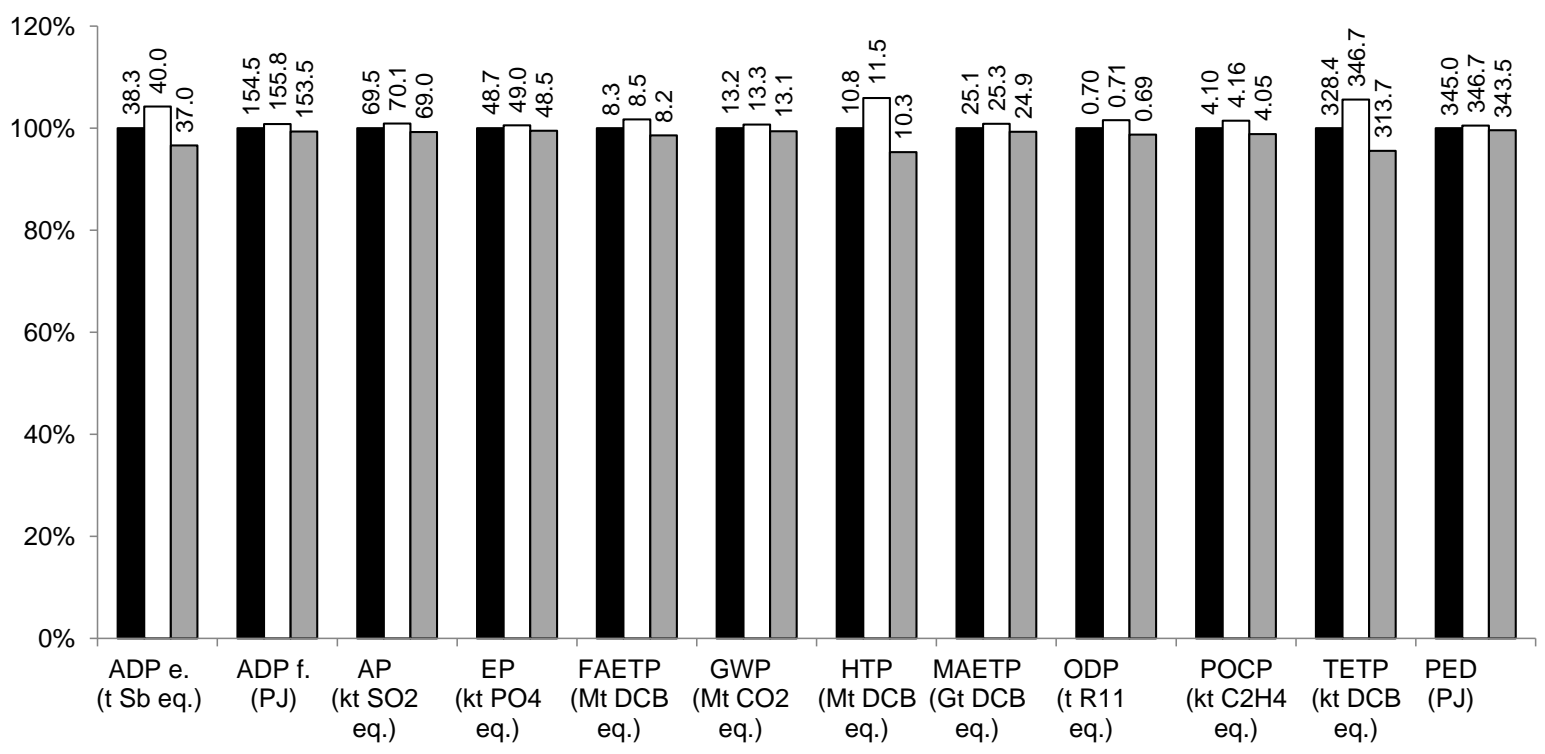

Fig. 5. Comparison of annual environmental impacts of kettles in the EU28 assuming different durability [Basis: 145.2 million units. For impacts nomenclature, see Fig. 3].

The savings in the primary energy demand with respect to the current situation are estimated at 32.1 PJ/yr for the water-efficiency scenario and $4 \mathrm{PJ} / \mathrm{yr}$ for the temperaturecontrol scenario (Fig. 6). While the latter is below the threshold of $7 \mathrm{PJ} / \mathrm{yr}$, the former is well above. Therefore, even with the Brexit and the reduced excess of the boiled water, the savings associated with the eco-design improvement to improve water efficiency are significant and justify development of a specific eco-design regulation for kettles.

\section{-Current situation (sensitivity) $\quad$ Improved water efficiency (sensitivity) $\quad$ Temperature control (sensitivity)}

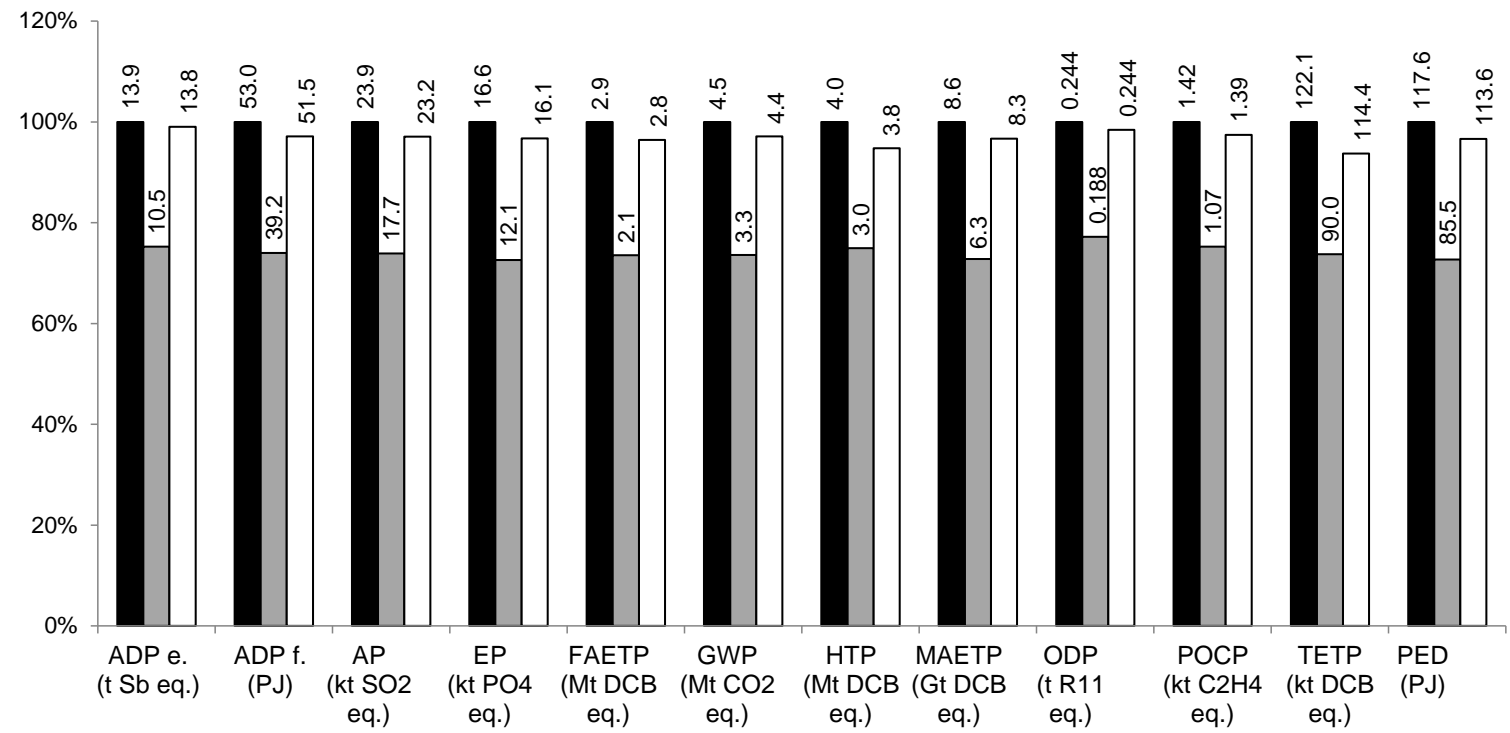

Fig. 6. Sensitivity analysis considering the effects on the annual EU28 impacts of lower number of kettles in the EU due to the Brexit and lower volume of water for two scenarios: improved water efficiency and temperature control. [Basis: 90.3 million kettles and $837 \mathrm{~L}$ water boiled/kettle/yr. For the assumptions see sections 2.1.3.1 and 2.1.4. For impacts nomenclature, see Fig. 3). 
Fig. 6 also shows that the depletion of resources, another key criterion considered by the European Commission, could also be reduced significantly in the water-efficiency scenario (3.5 t Sb eq./yr) even if the Brexit and a reduced excess of water are considered. For example, this would mean that the consumption of $1239 \mathrm{t} \mathrm{Cu/yr}$ would be avoided at the EU level. The other impacts would also be reduced significantly. This includes the avoidance of $1192 \mathrm{kt} \mathrm{CO}_{2}$ eq. in the water-efficiency scenario and $130 \mathrm{kt} \mathrm{CO}_{2}$ eq. in the temperaturecontrol scenario. Based on the data in Winkler et al. (2014), this is equivalent to the annual GHG emissions of 1.06 million and 115,000 light-duty vehicles, respectively.

\section{Conclusions}

This study has conducted the first comprehensive LCA of plastic, metallic and eco-kettles. The use stage is the main contributor $(>80 \%)$ to all environmental impacts for all three kettle types, due to the use of electricity to boil water. The raw materials have a noticeable contribution to the depletion of elements and human and terrestrial toxicity $(7 \%-16 \%)$. The environmental performance of plastic kettles is slightly better than the metallic for all the impact categories $(<2 \%)$, with the greatest difference for depletion of elements, human and terrestrial toxicity (5\%-10\%). Therefore, it can be concluded that the material of kettle body does not influence significantly the impacts and that for environmental improvements the focus should be on the use stage. The eco-kettles, with use-related improvements in water efficiency and temperature control, reduce the impacts over the entire life cycle by $30 \%-35 \%$ in comparison with plastic kettles and $32 \%-38 \%$ in comparison with the metallic.

The effects at the EU level of changes in kettle durability and energy efficiency have been analysed as they have been identified as potential major criteria for a future EU eco-design regulation. For durability, the results show that increasing the lifetime to seven years (from the current average of 4.4 years) would only save $3-5 \%$ of abiotic elements and human and terrestrial toxicity and less than $1.5 \%$ of the other impacts; the reduction in primary energy demand would also be small (1.4 PJ/yr). Therefore, the results suggest that the increase in durability should not be the main eco-design concern for EU regulation for kettles. However, possible future trends, such as decreased availability of scarce raw materials or improvements in the electricity mix or energy efficiency, could increase the relative environmental significance of material resources and, therefore, justify the necessity of increasing the durability to keep improving the environmental footprint of kettles.

The environmental effects at the EU level of applying the two energy-efficiency improvements already available on the market (water dosing and temperature control) have also been evaluated. Reducing the excess of water boiled would decrease all the impacts by $31 \%-33 \%$ compared to the current situation. The potential reduction in primary energy demand (up to $112.4 \mathrm{PJ} / \mathrm{yr}$ ) justifies by itself the necessity of an eco-design regulation for kettles. The environmental benefits for other impacts would also be significant. For example, GHG emissions avoided per year would be more than double the emissions of Malta and the maximum water savings in the use stage would be similar to the annual water consumption for household purposes in Slovenia. The implementation of dual chamber technology that allows for boiling the exact amount of water desired should be inexpensive and easy to incorporate by producers, but in depth cost analysis should be conducted in future studies. In parallel, as proposed in other studies, appropriate consumer engagement programmes can be developed to highlight the importance of boiling only the amount of water needed and encourage behavioural change. However, this can affect consumer convenience as filling a full kettle once a day is much easier than having to fill it each time when needed. The ecokettle with two chambers is helpful because the consumers can fill up the external chamber once a day and then dose the exact amount of water needed to the internal chamber by a simple push of a button.

Compared with conventional kettles, designs which allow the user to select the water heating temperature would lead to only $2-5 \%$ reductions in the impacts and no water savings. 
Considering the complexity of the electronic system needed also suggests that it should not be mandatory in a future eco-design regulation. However, the cost and feasibility of implementation for producers should be considered before a final decision. This improvement, if implemented, would also need a public information campaign to make consumers aware of the best temperature for each type of drink and to highlight the potential environmental and economic advantages.

Finally, the results at the EU level have been tested through a sensitivity analysis that considered the lowest possible water and related electricity consumption, combined with the effects of reduced number of kettles in use due to the UK exit from the EU. Even under these assumptions, the development of an eco-design regulation for kettles is justifiable as it could save 32.1 PJ/yr of primary energy demand as well as reducing other impacts, including depletion of elements (3.5 t Sb eq./yr) and global warming potential (1192 kt $\mathrm{CO}_{2}$ eq./yr).

Therefore, the results of this study suggest that a future eco-design regulation should focus on reducing the water use and related energy-saving measures. Future studies should also consider a greater variety of kettle designs used in different EU countries to gauge the effect of design on the impacts and help guide development of the eco-regulation.

\section{Acknowledgments}

This work has been funded by the Sustainable Consumption Institute at the University of Manchester and the UK Engineering and Physical Sciences Research Council (EPSRC, Gr. no. EP/F007132/1). The authors gratefully acknowledge this funding. The authors are also grateful to Roy Kershaw at the University of Manchester for his help with the disassembly of the kettles.

\section{Appendix A. Supplementary data}

The Supporting information includes data on electricity consumption and efficiency of the kettles; the EU electricity mix; hotspots in the life cycle of the kettles; and the annual environmental impacts of kettles in the EU28 for the current situation and improved energyefficiency scenarios. 


\section{References}

AEA Technology, 2008a. Market Transformation Programme BNCK01: Assumptions underlying the energy projections of cooking appliances. Final report from AEA Technology developed for Department for Environment, Food and Rural Affairs (DEFRA), Oxfordshire (United Kingdom) 13 pp.

AEA Technology, 2008b. Market Transformation Programme BNCK06: Trends in kettle type and usage and possible impact on energy consumption. Final report from AEA Technology developed for Department for Environment, Food and Rural Affairs (DEFRA), Oxfordshire (United Kingdom) 4 pp.

Amienyo, D., Camilleri, C., Azapagic, A., 2014. Environmental impacts of consumption of Australian red wine in the UK. J. Clean. Prod. 72, 110-119.

Andrae, A.S.G., 2016. Life-Cycle Assessment of Consumer Electronics: A review of methodological approaches. IEEE Consum. Electron. Mag. 5 (1), pp. 51-60.

Ashby, M.F., 2013. Chapter 8 - Case studies: Eco-audits, In Materials and the Environment (Second Edition), Butterworth-Heinemann, Boston (USA) 193-225 pp.

Azapagic, A., Bore, J., Cheserek, B., Kamunya, S., Elbehri, A., 2016. The global warming potential of production and consumption of Kenyan tea. J. Clean. Prod. 112, 4031-4040.

Bosch, 2016. Kettle Styline TWK8633GB Black. Available at: http://www.boschhome.co.uk/products/kettles-toasters/kettles/TWK8633GB.html\#tab5 (last access: 20-102017).

BSI, 2011. Publicly Available Specification PAS 2050:2011. Specification for the Assessment of the Life Cycle Greenhouse Gas Emissions of Goods and Services. Report from British Standards Institution (BSI), London (UK) 45 pp.

Büsser, S., Jungbluth, N., 2009. The role of flexible packaging in the life cycle of coffee and butter. Int. J. Life Cycle Assess. 14 (1), 80-91.

Carbon footprint, 2016. Household energy consumption. Available at: http://www.carbonfootprint.com/energyconsumption.html (last access: 20-10-2017)

CBI Market Intelligence, 2015. CBI trade statistics: Tea. Report from CBI Market Intelligence, The Hague (The Netherlands) $10 \mathrm{pp}$.

CECED, 2014. CECED comments on the preparatory study to establish the Ecodesign Working Plan 2015-2017. Report from European Committee of Domestic Equipment Manufacturers (CECED), Brussels (Belgium) $6 \mathrm{pp}$.

Cichorowski, G., Joa, B., Hottenroth, H., Schmidt, M., 2015. Scenario analysis of life cycle greenhouse gas emissions of Darjeeling tea. Int. J. Life Cycle Assess. 20 (4), 426-439.

Clear, M., 2016. How to buy the best electric kettle. Available at: http://www.which.co.uk/reviews/kettles/article/how-to-buy-the-best-electric-kettle (last access: 20-10-2017).

Cox, J., Griffith, S., Giorgi, S., King, G., 2013. Consumer understanding of product lifetimes. Resour. Conserv. Recy. 79, 21-29.

Defra, 2009. Saving Energy Through Better Products and Appliances. A report on analysis, aims and indicative standards for energy efficient products $2009-2030$. Department for Environment, Food and Rural Affairs (DEFRA), London (UK) 160 pp.

Deng, L., Babbitt, C.W., Williams, E.D., 2011. Economic-balance hybrid LCA extended with uncertainty analysis: case study of a laptop computer. J. Clean. Prod. 19, 1198-1206

Ecoinvent Centre, 2010. Ecoinvent v.2.2 Database. Swiss Centre for Life Cycle Inventories, Dübendorf (Switzerland).

EMF, 2015. Towards a circular economy: Business rationale for an accelerated transition. Report from Ellen MacArthur Foundation (EMF), Cowes (UK) 20 pp.

ENTSO-E, 2016. ENTSO-E Yearly Statistics \& Adequacy Retrospect 2014. Report from European Network of Transmission System Operators for Electricity (ENTSO-E), Brussels (Belgium) $68 \mathrm{pp}$.

EST, 2013. At home with water. Report from Energy Saving Trust (EST), London (UK) 36 pp. 
Euromonitor International, 2014a. Instant Coffee: Versatility and Convenience Drive Growth. Report from Euromonitor International, London (UK) 46 pp.

Euromonitor International, 2014b. Hot Drinks in 2014: New Occasions, New Consumers, New Opportunities. Report from Euromonitor International, London (UK) 47 pp.

European Commission, 2012. Establishment of the Working Plan 2012-2014 under the Ecodesign Directive. European Commission staff working document, Brussels (Belgium) $17 \mathrm{pp}$.

European Commission, 2014. On the review of the list of critical raw materials for the EU and the implementation of the Raw Materials Initiative. Communication from the Commission to the European Parliament, the Council, the European Economic and Social Committee and the Committee of the Regions, Brussels (Belgium) 7 pp.

European Commission, 2015. Closing the loop - An EU action plan for the Circular Economy. Communication from the Commission to the European Parliament, the Council, the European Economic and Social Committee and the Committee of the Regions, Brussels (Belgium) $21 \mathrm{pp}$.

European Parliament, 2012. Directive 2012/19EU of the European parliament and of the council of 4 July 2012 on waste electrical and electronic equipment (WEEE). Off. J. Eur. Union L 197, 38-71 24.7.2012.

European Parliament, European Council, 2009. Decision No 406/2009/EC of the European parliament and of the Council of 23 April 2009 on the effort of Member States to reduce their greenhouse gas emissions to meet the Community's greenhouse gas emission reduction commitments up to 2020. Off. J. Eur. Union L 140, 136-158 5.6.2009.

Eurostat, 2015. Water statistics. Available at: http://ec.europa.eu/eurostat/statisticsexplained/index.php/Water_statistics (last access: 20-10-2017).

Eurostat, 2016a. Number of private households by household composition, number of children and working status within households. Available at: http://ec.europa.eu/eurostat /web/products-datasets/-/lfst_hhnhwhtc (last access: 20-10-2017).

Eurostat, 2016b. Packaging waste statistics. Available at: http://ec.europa.eu/eurostat /en/web /products-datasets/-/ENV_WASPAC (last access: 20-10-2017).

Fischer, C., Gensch, C. O., Prieß, R., Bromme, E., Mudgal, S., Tinetti, B., Lemeillet, A., Thonier, G., Goodman, P., 2014. Preparatory Study to establish the Ecodesign Working Plan 2015-2017 implementing Directive 2009/125/EC Task 3 Draft Final. Report from BIO by Deloitte (BIO), Oeko-Institut and ERA Technology to the European Commission, Directorate General for Enterprise and Industry, Neuilly-sur-Sein (France) 340 pp.

Foekema, H., van Thiel, L., Lettinga, B., 2008. Watergebruik thuis 2007. Report from Vewin, Amsterdam (The Netherlands) $138 \mathrm{pp}$.

Gallego-Schmid, A., Mendoza, J.M.F., Jeswani, H.K., Azapagic, A., 2016. Life cycle environmental impacts of vacuum cleaners and the effects of European regulation. Sci. Total Environ. 559, 192-203.

Gallego-Schmid, A., Mendoza, J.M.F., Azapagic, A., 2018. Environmental assessment of microwaves and the effect of European eco-design and waste management legislation. Submitted to Journal. Sci. Total Environ. 618, 487-499.

Guinee, J.B., Gorrèe, M., Heijungs, R., Huppes, G., Kleijn, G.R., van Oers, R.L., Wegener, L., Sleeswijk, A., Suh, S., de Haes, H.A. Udo, de Bruijn, H., van Duin, H.R., Huijbregts, M.A.J., 2001. Life Cycle Assessment, an Operational Guide to the ISO Standards. Part 2a: Guide. Kluwer Academic Publishers, Dordrecht (the Netherlands) 101 pp.

Hickman, L., 2010. Three of the best eco kettles. Available at: https://www.theguardian.com/environment/2010/sep/15/best-eco-kettles (last access: 2010-2017).

Hopkinson, L., James P., 2011. Life Cycle Energy and Environmental Impacts of Computing Equipment - A June 2011 Update to a 2009 SustelT Report. Report from Higher Education Environmental Performance Improvement Project, Bradford (UK) 10 pp.

Humbert, S., Loerincik, Y., Rossi, V., Margni, M., Jolliet, O., 2009. Life cycle assessment of spray dried soluble coffee and comparison with alternatives (drip filter and capsule espresso). J. Clean. Prod. 17 (15), 1351-1358. 
ISO, 2006a. ISO14040:2006. Environmental Management - Life Cycle Assessment Principles and Framework. ISO Standards, Geneva (Switzerland) 20 pp.

ISO, 2006b. ISO14044:2006 Environmental management - Life Cycle Assessment Requirements and Guidelines. ISO standards, Geneva (Switzerland) 46 pp.

JRC, 2014. Emission Database for Global Atmospheric Research (EDGAR), version 4.2. Available at: http://edgar.jrc.ec.europa.eu/overview.php?v=CO2ts\%201990-2011\&sort= des9 (last access: 20-10-2017).

Kärnä, A., Malmström, P., 2002. Environmentally oriented product design. A guide for companies in the Electrical and Electronics Industry. Report from Federation of Finnish Electrical and Electronics Industry, Helsinki (Finland) 199 pp.

Kemna, R., Azaïs,N., van Elburg, M., van der Voort, M., Li, W., 2011. Part 2: Environmental policies \& data. Methodology for Ecodesign of Energy-related Products. Final report developed from Van Holsteijn en Kemna B.V. (VHK) consulters for European Commission, Brussels (Belgium) 200 pp.

Monfared, B., Furberg, R., Palm, B., 2014. Magnetic vs. vapor-compression household refrigerators: a preliminary comparative life cycle assessment. Int. J. Refrig. 42, 69-76.

Murray, D., Liao, J., Stankovic, L., Stankovic, V., 2015. How to make efficient use of kettles: Understanding usage patterns. Paper presented at $8^{\text {th }}$ International Conference on Energy Efficiency in Domestic Appliances and Lighting, Lucerne (UK), 26/08/15 28/08/15, pp. 1-13.

Palmer, J., Terry, N., 2014. Powering the Nation 2: Electricity profiles, appliances and energy drivers. Report prepared by Cambridge Architectural Research, Cambridge Energy, Loughborough University and Element Energy for Department of Energy \& Climate Change (DECC) and the Department for Environment, Food and Rural Affairs (DEFRA), Cambridge (UK) $33 \mathrm{pp}$.

Park, P.J., Tahara, K., Inaba, A., 2007. Product quality-based eco-efficiency applied to digital cameras. J. Environ. Manag. 83, 158-170.

PE International, 2014. Best Practice LCA: End-of-Life Modelling. PE International, Leinfelden-Echterdingen (Germany) $32 \mathrm{pp}$.

Plastics Europe, 2014. Polyoxymethylene (POM). Eco-profiles and Environmental Product Declarations of the European Plastics Manufacturers. Plastics Europe, Brussels (Belgium) $28 \mathrm{pp}$.

Product creation, 2006. Eco kettle technical report summary. Report from Product creation, West Sussex (UK) 3 pp.

Sauer, J., Rüttinger, B., 2004. Environmental conservation in the domestic domain: The influence of technical design features and person-based factors. Ergonomics 47 (10), 1053-1072.

Schmidt, J.H., 2012. Plastberegner.dk-LCA Tool for Plastics Converters in Denmark. Documentation of the Tool and Database. Report from 2.-0 LCA Consultants, Aalborg (Denmark) $126 \mathrm{pp}$.

Sea distance, 2017. Distance from Shanghai port to Rotterdam port. Available at: http:// www.sea-distances.org (Last access: 18/12/2017).

Telenko, C, Seepersad, C.C., 2010. A methodology for identifying environmentally conscious guidelines for product design. J. Mech. Des.-T. ASME 132 (9), 0910091-0910099.

Thomas, N.J., Chang, N.B., Qi, C., 2012. Preliminary assessment for global warming potential of leading contributory gases from a 40-in LCD flat-screen television. Int. J. Life Cycle Assess. 17, 96-104.

Thinkstep, 2017. GaBi 6.5 database. Thinkstep, Leinfelden-Echterdingen (Germany).

UK Tea \& Infusion Association, 2016. Make a perfect Brew. Available at: https://www.tea.co.uk/make-a-perfect-brew (Last access: 20-10-2017).

van Elburg, M., van der Voort, M., van den Boorn, R., Kemna, R., Li, W., 2011. Study on Amended Working Plan under the Ecodesign Directive (remaining energy-using products and new energy-related products). Final report Task 3 developed from Van Holsteijn en Kemna B.V. (VHK) consulters for European Commission, Delft (The Netherlands), 247 pp. 
VHK, 2010. Quooker ${ }^{\circledR}$ Energy Analysis. Report developed from Van Holsteijn en Kemna B.V. (VHK), Delft (The Netherlands) 61 pp.

Via Michellin, 2017. Maps and route planner. Available at: http://www.viamichelin.co.uk/ (Last access: 18/12/2017).

Winkler, S.L., Wallington, T.J., Maas, H., Hass, H., 2014. Light-duty vehicle $\mathrm{CO}_{2}$ targets consistent with 450 ppm CO 2 stabilization. Environ. Sci. Technol. 48 (11), 6453-6460.

World Ship Council, 2013. Top 50 world containers ports. Available at: http://www.worldshipping.org/about-the-industry/global-trade/top-50-world-container-ports (Last access: 20/10/2017).

WRAP, 2010. Environmental assessment of consumer electronic products. A review of high volume consumer electrical products through Lifecycle Assessments, to compare their relative environmental impacts and identify future trends. Report from Waste \& Resources Action Programme (WRAP), Banbury (UK) 24 pp.

WRAP, 2012a. Part 1: Results Report. Reducing the environmental and cost impacts of electrical products. Report from Waste \& Resources Action Programme (WRAP), Banbury (UK) $43 \mathrm{pp}$.

WRAP, 2012b. Part 3: Methodology Report. Reducing the environmental and cost impacts of electrical products. Report from Waste \& Resources Action Programme (WRAP), Banbury (UK) $83 \mathrm{pp}$.

WRAP, 2014. Durable Kettles. Report from Waste \& Resources Action Programme (WRAP), Banbury (UK) $23 \mathrm{pp}$.

Xue, M., Kendall, A., Xu, Z., Schoenung, J.M., 2015. Waste Management of Printed Wiring Boards: A Life Cycle Assessment of the Metals Recycling Chain from Liberation through Refining. Environ. Sci. Technol. 49 (2), 940-947.

$\mathrm{Yu}$, J., Williams, E., Ju, M., 2010. Analysis of material and energy consumption of mobile phones in China. Energy Policy 38, 4135-4141.

Zimmermann, J.P., Evans, M., Griggs, J., King, N., Harding, L., Roberts, P., Evans, C., 2012. Household Electricity Survey: A study of domestic electrical product usage. Report from Intertek, Milton Keynes (UK) 600 pp. 


\section{Life cycle environmental evaluation of kettles: Recommendations for the development of eco-design regulations in the European Union}

Alejandro Gallego-Schmid*, Harish Kumar Jeswani, Joan Manuel F. Mendoza and Adisa Azapagic

\section{Supporting information}

Table S1. Electricity consumption and efficiency for plastic, metallic and eco kettles ${ }^{a}$

\begin{tabular}{|c|c|c|c|c|}
\hline \multirow[b]{2}{*}{ Parameters } & \multicolumn{4}{|c|}{ Electricity consumption (Wh) and heating efficiency (\%) } \\
\hline & Plastic kettle & Metallic kettle & Eco-kettle & Average \\
\hline $80 \stackrel{\circ}{\circ}$ & - & - & & \\
\hline $0.25 \mathrm{~L}$ & - & - & $27.0(86 \%)$ & $27.0(86 \%)$ \\
\hline $0.50 \mathrm{~L}$ & - & - & $47.0(86 \%)$ & $47.0(86 \%)$ \\
\hline $0.75 \mathrm{~L}$ & - & - & 68.7 (89\%) & 68.7 (89\%) \\
\hline $1 \mathrm{~L}$ & - & - & $91.6^{b}(89 \%)$ & $91.6^{b}(89 \%)$ \\
\hline \multicolumn{5}{|l|}{$90^{\circ} \mathrm{C}$} \\
\hline $0.25 \mathrm{~L}$ & - & - & $29.0(80 \%)$ & $29.0(80 \%)$ \\
\hline $0.75 \mathrm{~L}$ & - & - & $56.0(83 \%)$ & $56.0(83 \%)$ \\
\hline $0.50 \mathrm{~L}$ & - & - & $81.3(86 \%)$ & $81.3(86 \%)$ \\
\hline $1 \mathrm{~L}$ & - & - & $108.4^{\mathrm{b}}(86 \%)$ & $108.4^{\mathrm{b}}(86 \%)$ \\
\hline \multicolumn{5}{|l|}{$100 \stackrel{\circ}{C}$} \\
\hline $0.25 \mathrm{~L}$ & 32.7 (80\%) & $33.0(79 \%)$ & 33.7 (78\%) & 33.1 (79\%) \\
\hline $0.50 \mathrm{~L}$ & 65.7 (79\%) & $65.0(80 \%)$ & $65.3(80 \%)$ & $65.3(80 \%)$ \\
\hline $0.75 \mathrm{~L}$ & 92.0 (84\%) & 93.7 (84\%) & $90.3(87 \%)$ & $92.0(85 \%)$ \\
\hline $1 \mathrm{~L}$ & $122.0(86 \%)$ & $124.3(84 \%)$ & $120.4^{b}(86 \%)$ & $122.2(85 \%)$ \\
\hline
\end{tabular}

${ }^{a}$ Results represent the average of five measurements. Initial water temperature: $10{ }^{\circ} \mathrm{C}$. Values in brackets show heating efficiencies. These have been estimated by dividing the ideal energy consumption by the measured values. The former is calculated by multiplying the change in temperature from the initial to the desired and different water volume by the specific heating capacity of water.

${ }^{b}$ The maximum available volume of water to be heated in the eco-kettle is $0.8 \mathrm{~L}$ (corresponding to the volume of the inner chamber). Thus, the values for $1 \mathrm{~L}$ have been calculated assuming the same efficiency as for $0.75 \mathrm{~L}$. Note that volume of the outer chamber is $1.5 \mathrm{~L}$ but only a maximum of $0.8 \mathrm{~L}$ can be dosed into the inner chamber and boiled at any one time.

Table S2 Electricity mix in the European Union (EU28) in 2014 (ENTSO-E, 2016)

\begin{tabular}{lc}
\hline Source of electricity & EU28 2014 (\%) \\
\hline Nuclear & 30.1 \\
Lignite & 10.8 \\
Hard coal & 15.7 \\
Natural gas & 13.3 \\
Oil & 1.3 \\
Wind & 8.5 \\
Solar & 3.2 \\
Biomass & 3.6 \\
Hydropower (renewable) & 12.2 \\
Hydropower (others) & 1.3 \\
\hline
\end{tabular}


Table S3. Hotspots in the life cycle of the plastic kettle

\begin{tabular}{|c|c|c|c|c|}
\hline Life cycle stage & Impact $^{\mathrm{a}}$ & $\begin{array}{c}\text { Contribution } \\
\text { to the total } \\
(\%)\end{array}$ & Main contributor & $\begin{array}{c}\text { Contribution } \\
\text { to life cycle } \\
\text { stage (\%) }\end{array}$ \\
\hline \multicolumn{5}{|c|}{ Raw materials (copper) } \\
\hline \multicolumn{5}{|c|}{ Raw materials (stainless steel) } \\
\hline & ADP e & 2.4 & Cr consumption & 22.7 \\
\hline & HTP & 6.0 & Air emission of $\mathrm{Cr}$ & 59.6 \\
\hline & TETP & 7.0 & Air emission of $\mathrm{Cr}$ & 93.5 \\
\hline \multicolumn{5}{|l|}{ Use (electricity) } \\
\hline & ADP e & 89.6 & $\mathrm{Cu}$ (electricity distribution) & 47.6 \\
\hline & ADP f & 97.9 & Fossil fuels consumption & 100 \\
\hline & AP & 97.9 & $\mathrm{SO}_{2}$ (coal burning) & 68.8 \\
\hline & EP & 98.9 & $\mathrm{PO}_{4}^{3-}$ (coal mining) & 73.2 \\
\hline & FAETP & 97.1 & $\mathrm{Ni}$ (coal mining) & 41.8 \\
\hline & GWP & 98.5 & $\mathrm{CO}_{2}$ (burning fossil fuels) & 90.4 \\
\hline & HTP & 90.7 & Se (coal mining) & 20.3 \\
\hline & MAETP & 98.4 & Be (coal mining) & 35.6 \\
\hline & ODP & 96.5 & Halon 1211 (natural gas transport) & 54.3 \\
\hline & POCP & 96.6 & $\mathrm{SO}_{2}$ (coal burning) & 47.1 \\
\hline & TETP & 92.0 & $\mathrm{Cr}$ (electricity distribution) & 83.2 \\
\hline & PED & 98.8 & $\mathrm{U}$ (nuclear energy) & 36.1 \\
\hline
\end{tabular}

Table S4. Hotspots in the life cycle of the metallic kettle

\begin{tabular}{|c|c|c|c|c|}
\hline Life cycle stage & Impact $^{\mathrm{a}}$ & $\begin{array}{c}\text { Contribution } \\
\text { to the total } \\
(\%)\end{array}$ & Main contributor & $\begin{array}{c}\text { Contribution } \\
\text { to life cycle } \\
\text { stage (\%) }\end{array}$ \\
\hline \multicolumn{5}{|c|}{ Raw materials (copper) } \\
\hline \multicolumn{5}{|c|}{ Raw materials (stainless steel) } \\
\hline & ADP e & 5.9 & Cr consumption & 36.0 \\
\hline & HTP & 14.1 & Air emission of $\mathrm{Cr}$ & 80.7 \\
\hline & TETP & 16.3 & Air emission of $\mathrm{Cr}$ & 95.7 \\
\hline \multicolumn{5}{|l|}{ Use (electricity) } \\
\hline & ADP e & 85.4 & Cu (electricity distribution) & 47.6 \\
\hline & ADP f & 97.9 & Fossil fuels consumption & 100 \\
\hline & $\mathrm{AP}$ & 98.0 & $\mathrm{SO}_{2}$ (coal burning) & 68.8 \\
\hline & EP & 98.7 & $\mathrm{PO}_{4}{ }^{3-}$ (coal mining) & 73.2 \\
\hline & FAETP & 95.0 & $\mathrm{Ni}$ (coal mining) & 41.8 \\
\hline & GWP & 98.3 & $\mathrm{CO}_{2}$ (burning fossil fuels) & 90.4 \\
\hline & HTP & 82.4 & Se (coal mining) & 20.3 \\
\hline & MAETP & 97.7 & Be (coal mining) & 35.6 \\
\hline & ODP & 97.0 & Halon 1211 (natural gas transport) & 54.3 \\
\hline & POCP & 96.6 & $\mathrm{SO}_{2}$ (coal burning) & 47.1 \\
\hline & TETP & 82.4 & $\mathrm{Cr}$ (electricity distribution) & 83.2 \\
\hline & PED & 98.7 & $\mathrm{U}$ (nuclear energy) & 36.1 \\
\hline
\end{tabular}

\footnotetext{
${ }^{a}$ For impacts nomenclature, see Table S3.
} 
Table S5. Hotspots in the life cycle of the eco kettle

\begin{tabular}{|c|c|c|c|c|}
\hline Life cycle stage & Impact $^{\mathrm{a}}$ & $\begin{array}{c}\text { Contribution } \\
\text { to the total } \\
(\%)\end{array}$ & Main contributor & $\begin{array}{c}\text { Contribution } \\
\text { to life cycle } \\
\text { stage (\%) }\end{array}$ \\
\hline \multicolumn{5}{|c|}{ Raw materials (copper) } \\
\hline \multicolumn{5}{|c|}{ Raw materials (stainless steel) } \\
\hline & $\mathrm{ADPe}$ & 5.8 & Cr consumption & 27.4 \\
\hline & HTP & 11.7 & Air emission of $\mathrm{Cr}$ & 70.9 \\
\hline & TETP & 13.4 & Air emission of $\mathrm{Cr}$ & 92.2 \\
\hline \multicolumn{5}{|l|}{ Use (electricity) } \\
\hline & ADP e & 80.2 & $\mathrm{Cu}$ (electricity distribution) & 47.6 \\
\hline & ADP f & 94.6 & Fossil fuels consumption & 100 \\
\hline & $\mathrm{AP}$ & 95.0 & $\mathrm{SO}_{2}$ (coal burning) & 68.8 \\
\hline & $\mathrm{EP}$ & 97.4 & $\mathrm{PO}_{4}{ }^{3-}$ (coal mining) & 73.2 \\
\hline & FAETP & 93.7 & $\mathrm{Ni}$ (coal mining) & 41.8 \\
\hline & GWP & 95.9 & $\mathrm{CO}_{2}$ (burning fossil fuels) & 90.4 \\
\hline & HTP & 82.4 & Se (coal mining) & 20.3 \\
\hline & MAETP & 96.5 & Be (coal mining) & 35.6 \\
\hline & ODP & 91.0 & Halon 1211 (natural gas transport) & 54.3 \\
\hline & POCP & 91.7 & $\mathrm{SO}_{2}$ (coal burning) & 47.1 \\
\hline & TETP & 84.9 & $\mathrm{Cr}$ (electricity distribution) & 83.2 \\
\hline & PED & 97.0 & $\mathrm{U}$ (nuclear energy) & 36.1 \\
\hline
\end{tabular}

${ }^{\mathrm{a}}$ For impacts nomenclature, see Table S3.

Table S6. Annual environmental impacts of kettles in the EU28 and contribution analysis for the current situation and improved energy-efficiency scenarios

\begin{tabular}{|c|c|c|c|c|c|c|c|c|c|}
\hline \multirow{2}{*}{ Impacts } & \multicolumn{3}{|c|}{ Current situation } & \multicolumn{3}{|c|}{ Water efficiency scenario $^{a}$} & \multicolumn{3}{|c|}{$\begin{array}{c}\text { Temperature control } \\
\text { scenario }^{\mathrm{a}}\end{array}$} \\
\hline & Total & Use & $\begin{array}{c}\text { Other } \\
\text { stages }^{b}\end{array}$ & Total & Use & $\begin{array}{c}\text { Other } \\
\text { stages }^{b}\end{array}$ & Total & Use & $\begin{array}{l}\text { Other } \\
\text { stages }^{b}\end{array}$ \\
\hline ADP e (t Sb eq.) & 38.3 & $90.9 \%$ & $9.1 \%$ & 26.6 & $87.4 \%$ & $12.6 \%$ & 37.5 & $89.4 \%$ & $10.6 \%$ \\
\hline ADP f (PJ) & 154.5 & $98.2 \%$ & $1.8 \%$ & 105.4 & $96.1 \%$ & $3.9 \%$ & 149.5 & $97.7 \%$ & $2.3 \%$ \\
\hline $\mathrm{AP}$ (kt SO 2 eq.) & 69.5 & $98.0 \%$ & $2.0 \%$ & 47.4 & $95.8 \%$ & $4.2 \%$ & 67.2 & $97.5 \%$ & $2.5 \%$ \\
\hline $\mathrm{EP}\left(\mathrm{kt} \mathrm{PO} \mathrm{P}_{4}\right.$ eq.) & 48.7 & $98.7 \%$ & $1.3 \%$ & 32.8 & $97.7 \%$ & $2.3 \%$ & 47.0 & $98.5 \%$ & $1.5 \%$ \\
\hline FAETP (Mt DCB eq.) & 8.3 & $96.3 \%$ & $3.7 \%$ & 5.7 & $94.3 \%$ & $5.7 \%$ & 8.0 & $96.2 \%$ & $3.8 \%$ \\
\hline GWP (Mt $\mathrm{CO}_{2}$ eq.) & 13.2 & $98.4 \%$ & $1.6 \%$ & 9.0 & $96.6 \%$ & $3.4 \%$ & 12.8 & $97.9 \%$ & $2.1 \%$ \\
\hline HTP (Mt DCB eq.) & 10.8 & $87.4 \%$ & $12.6 \%$ & 7.5 & $83.9 \%$ & $16.1 \%$ & 10.3 & $88.2 \%$ & $11.8 \%$ \\
\hline MAETP (Gt DCB eq.) & 25.1 & $98.1 \%$ & $1.9 \%$ & 16.9 & $96.9 \%$ & $3.1 \%$ & 24.2 & $97.9 \%$ & $2.1 \%$ \\
\hline ODP (t R11 eq.) & 0.70 & $96.7 \%$ & $3.3 \%$ & 0.49 & $91.9 \%$ & $8.1 \%$ & 0.68 & $95.4 \%$ & $4.6 \%$ \\
\hline POCP (kt $\mathrm{C}_{2} \mathrm{H}_{4}$ eq.) & 4.1 & $96.9 \%$ & $3.1 \%$ & 2.8 & $93.6 \%$ & $6.4 \%$ & 4.0 & $96.1 \%$ & $3.9 \%$ \\
\hline TETP (kt DCB eq.) & 328.4 & $88.0 \%$ & $12.0 \%$ & 225.4 & $85.5 \%$ & $14.5 \%$ & 311.0 & $89.4 \%$ & $10.6 \%$ \\
\hline PED (PJ) & 345.0 & $98.9 \%$ & $1.1 \%$ & 232.6 & $97.8 \%$ & $2.2 \%$ & 332.7 & $98.7 \%$ & $1.3 \%$ \\
\hline
\end{tabular}

\section{References}

ENTSO-E, 2016. ENTSO-E Yearly Statistics \& Adequacy Retrospect 2014. Report from European Network of Transmission System Operators for Electricity (ENTSO-E), Brussels (Belgium), 68 pp. 